Portland State University

PDXScholar

Civil and Environmental Engineering Master's

Project Reports

Summer 2019

\title{
The Gouda, the Bad, and the Ugly: Prioritizing Intersections for Pedestrian Safety in Tillamook, OR with Different Risk Estimation Methods
}

Kelly M. White

Portland State University

Follow this and additional works at: https://pdxscholar.library.pdx.edu/cengin_gradprojects

Part of the Civil and Environmental Engineering Commons Let us know how access to this document benefits you.

\section{Recommended Citation}

White, Kelly M., "The Gouda, the Bad, and the Ugly: Prioritizing Intersections for Pedestrian Safety in Tillamook, OR with Different Risk Estimation Methods" (2019). Civil and Environmental Engineering Master's Project Reports. 47.

https://doi.org/10.15760/CCEMP.44

This Project is brought to you for free and open access. It has been accepted for inclusion in Civil and Environmental Engineering Master's Project Reports by an authorized administrator of PDXScholar. Please contact us if we can make this document more accessible: pdxscholar@pdx.edu. 
The Gouda, the Bad, and the Ugly: Prioritizing Intersections for Pedestrian Safety in Tillamook, OR with Different Risk Estimation Methods

By

Kelly White

A research project report submitted in partial fulfillment of the requirement for the degree of

\section{MASTER OF SCIENCE \\ IN \\ CIVIL AND ENVIRONMENTAL ENGINEERING}

Project Advisor:

Chris Monsere

Portland State University

(C)2019 


\section{ACKNOWLEDGMENTS}

I would especially like to thank Chris Monsere for his guidance and encouragement throughout my time at Portland State University. Additionally, I would like to acknowledge the rest of my professors and classmates who encouraged me throughout graduate school.

I would like to express my sincere gratitude to my DKS Associates project team, specifically Garth Appanaitis and Amanda Deering, for providing me additional guidance and access to resources available from the City of Tillamook Transportation System Plan. 


\begin{abstract}
An abstract of the research report of Kelly White for the Master of Science in Civil and Environmental Engineering submitted on June 17 2019.

Title: The Gouda, the Bad, and the Ugly: Prioritizing Intersections for Pedestrian Safety in Tillamook, OR with Different Risk Estimation Methods

The following report explores five different pedestrian risk estimation methods at urban intersections. Six study intersections in Tillamook, Oregon were chosen as a case study to analyze each risk estimation method and apply the values to a project prioritization process. Ultimately, risk factors of both exposure and infrastructure contribute to the highest amount of risk for pedestrians. The Oregon Department of Transportation's State Planning and Research Report 779 was identified as the most comprehensive risk estimation method.
\end{abstract}




\section{TABLE OF CONTENTS}

1.0 INTRODUCTION ...............................................................................................................1

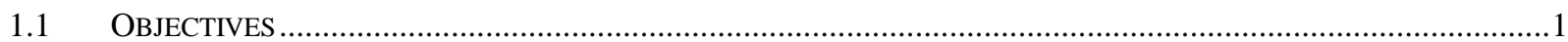

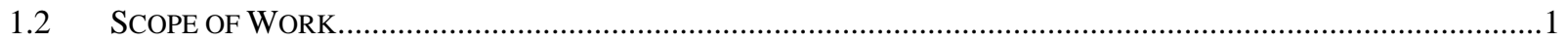

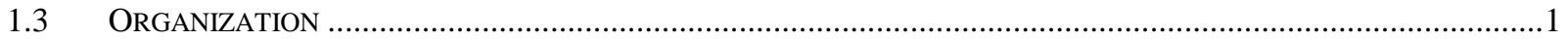

2.0 BACKGROUND....................................................................................................................

2.1 STUDY AREA ……………………………………………………………………………2

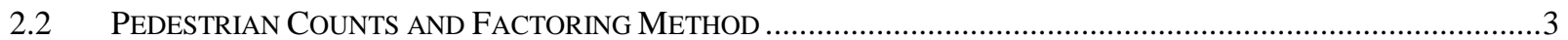

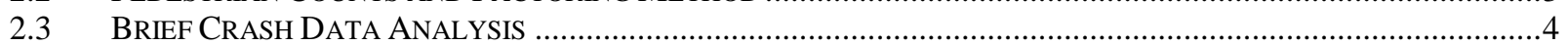

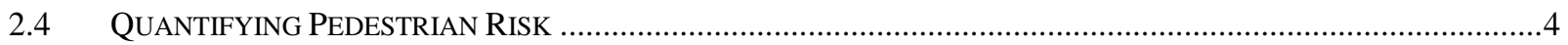

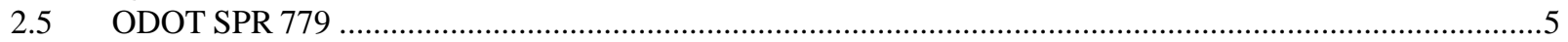

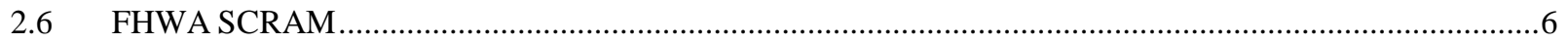

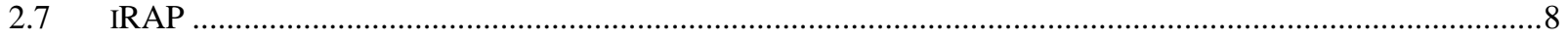

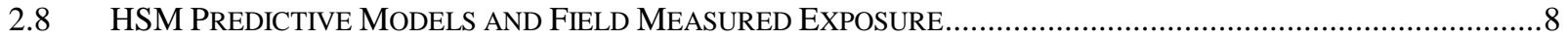

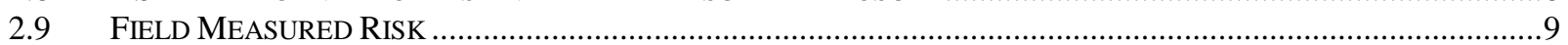

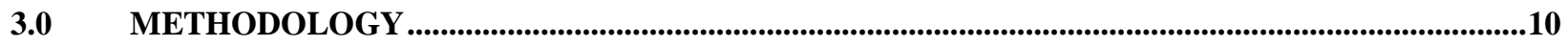

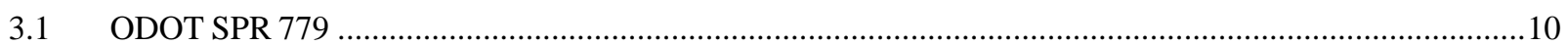

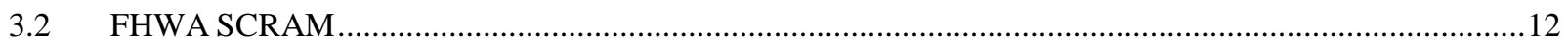

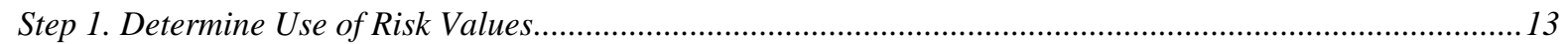

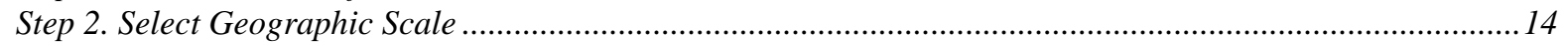

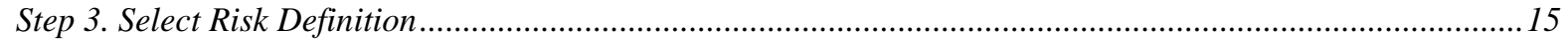

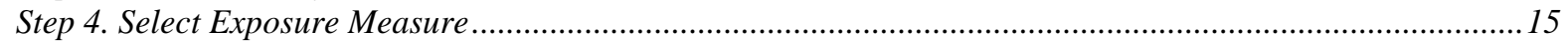

Step 5. Select Analytic Method to Estimate Exposure ...................................................................................... 17

Step 6. Use Analytic Method to Estimate Selected Exposure Measure .................................................................17

Step 7. Compile Other Required Data ........................................................................................................ 18

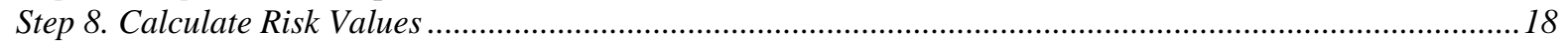

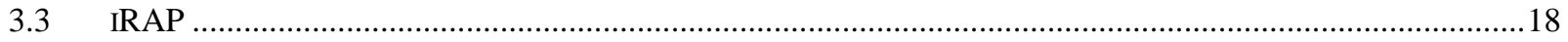

3.4 HSM PREDICTIVE MOdELS AND FIELD MEASURED EXPOSURE...........................................................21

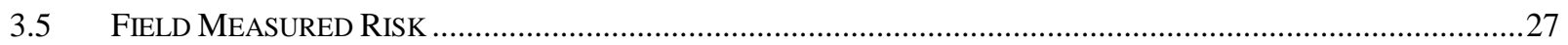

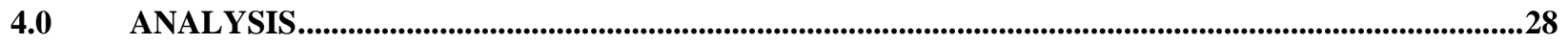

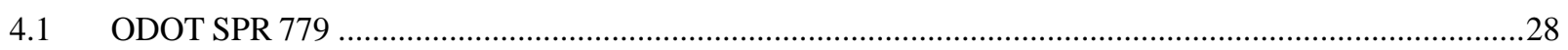

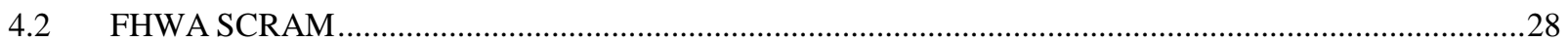

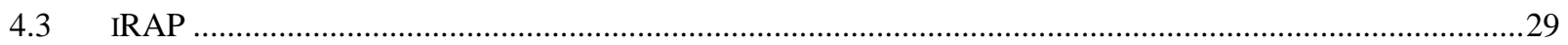

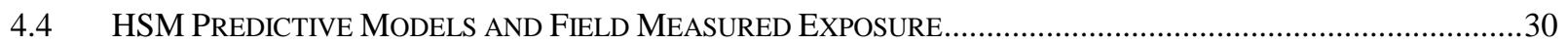

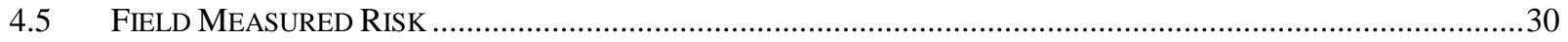

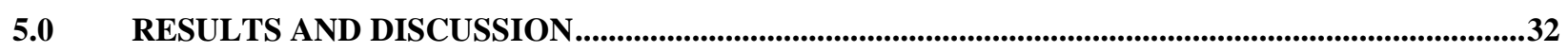

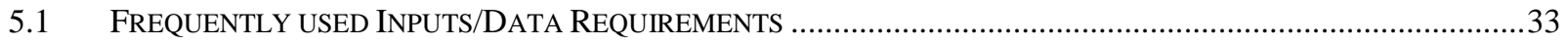

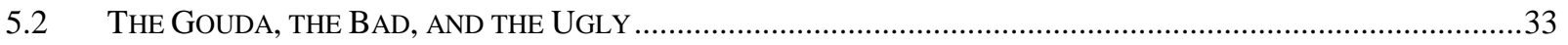

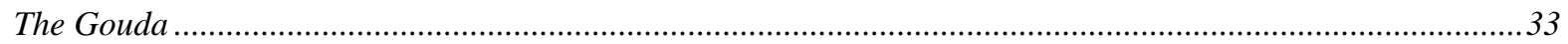

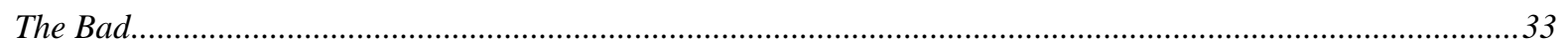

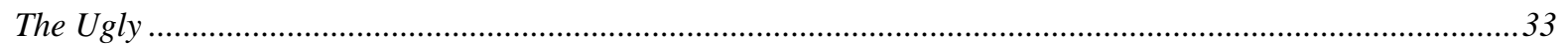

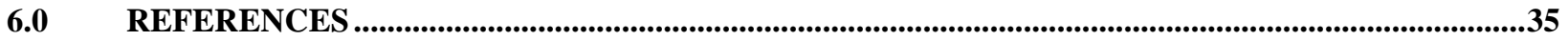




\section{LIST OF TABLES}

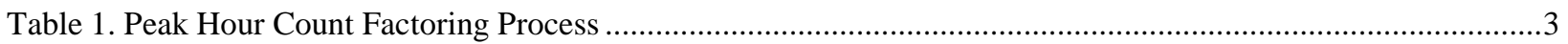

Table 2. Study Intersection Peak Hour Pedestrian Volumes .................................................................................

Table 3. Summary of Identified Risk Factors for Pedestrian Crashes .................................................................10

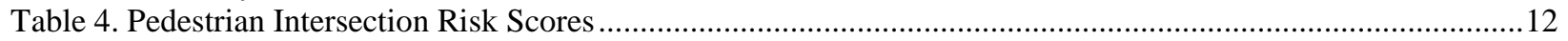

Table 5. Four Scale Categories in the Scalable Risk Assessment Process .............................................................14

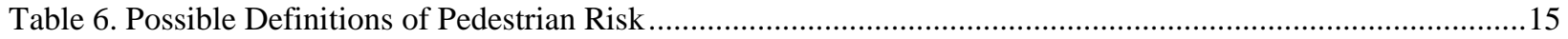

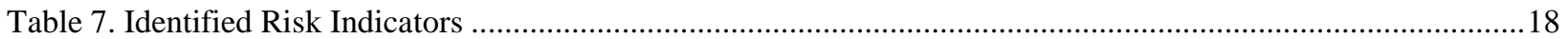

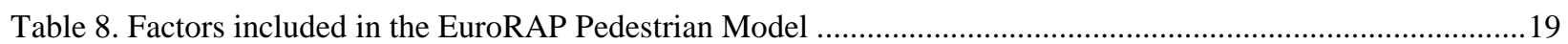

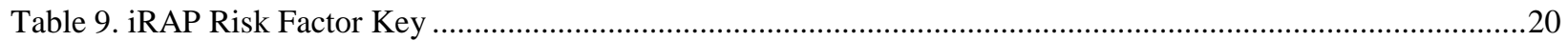

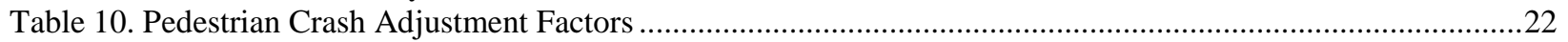

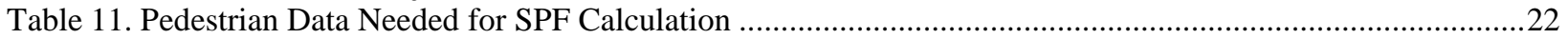

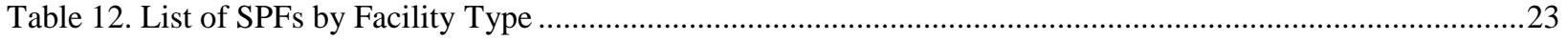

Table 13. SPFs for Vehicle-Pedestrian Collisions at Signalized Intersections (Table 12-14, HSM).........................24

Table 14. Crash Modification Factor $(C M F 1 p)$ for the Presence of Bus Stops near the Intersection ........................25

Table 15. Crash Modification Factor $(C M F 2 p)$ for the Presence of Schools near the Intersection...........................25

Table 16. Crash Modification Factor $(C M F 3 p)$ for the Number of Alcohol Sales Establishments near the Intersection

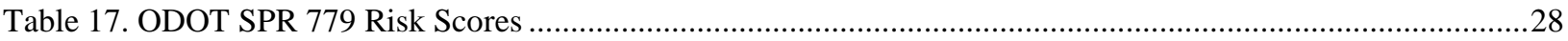

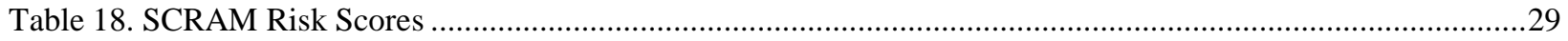

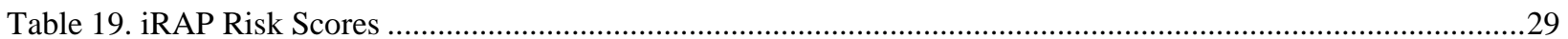

Table 20. HSM Predicitive Model and Field Measured Exposure Risk Scores ..............................................................30

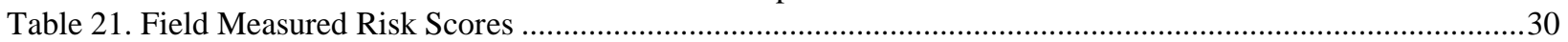

Table 22. Comparison of Risk Estimation Models at each Study Intersection ............................................................32

Table 23. Minor Roadway Trend among Study Intersection Rik Ranks ..................................................................32 


\section{LIST OF FIGURES}

Figure 1. Study Intersections in Tillamook, Oregon along US-101 .2

Figure 2. Risk Matrix, Darker Shading Indicates Higher Risk (Berdica, 2002) ....................................................5

Figure 3. Eight Steps for Scalable Risk Assessment for Pedestrians and Bicyclists (SCRAM) ................................

Figure 4. Selecting Key Parameters Based on Use(s) of Risk Values .........................................................13

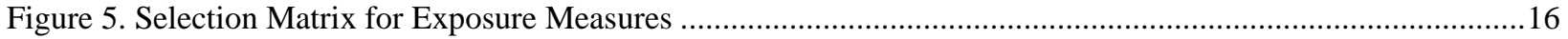

Figure 6. Pedestrian (crossing side road at intersection) external flow risk factors ..............................................21

Figure 7. Local Calibration Factors developed for Oregon by ODOT for HSM Predictive Models ........................26 


\subsection{INTRODUCTION}

As agencies across the United States are adopting programs and initiatives to cut down on traffic deaths, pedestrian safety has emerged as a key component for enhancing overall roadway safety. Pedestrians are arguably the road's most vulnerable user, and whether short distance or long distance, at least every single person is a pedestrian on the roadway network at some point in their day. Transportation planning and design efforts have increasingly included pedestrian safety projects as priorities but are often generalized on a corridor level due to the large number of existing low-quality pedestrian facilities that exist in most communities today. When plan implementation rolls around, agencies often struggle to prioritize which facilities require the most need with quantitative justification.

In recent years, local and national agencies have addressed this issue of pedestrian and bicycle project prioritization by developing measures of risk to determine which intersections or segments put pedestrians in the most amount of danger according to specific characteristics of the roadway at each intersection. The following paper will use a case study in Tillamook, Oregon to compare multiple risk calculation methods that have been developed at the state level, national level, and in the private sector to understand how pedestrian projects are being prioritized throughout the world.

\subsection{Objectives}

The purpose of this research is to conduct a review of pedestrian risk calculation methods developed by agencies at varying levels of jurisdiction. The review will include methods developed by the Oregon Department of Transportation (ODOT), the Federal Highway Administration (FHWA), and the International Roadway Assessment Programme (iRap). These methods will be compared to a risk calculation measured in the field using recently collected pedestrian count data at the study intersections.

\subsection{Scope of Work}

Risk will be calculated using the methods listed above at six intersections in Tillamook, Oregon where recent pedestrian count data was collected for their 2018 Transportation System Plan. All six intersections are located along US-101 inside of Tillamook city limits. A full analysis of the segment of US-101 through the City will not be included in the scope of this report.

\subsection{Organization}

The following chapter provides background on the development of each risk assessment method. The methodology chapter describes each risk assessment method in detail, including the necessary data elements for calculation. The analysis section will display the results of each risk calculation, which is followed by a discussion of the results and commentary on the similarities and differences between each method and its output. 


\subsection{BACKGROUND}

The following section provides study area context for this research, background on why risk estimations can be used to quantify pedestrian safety, and brief descriptions of how each risk estimation method used in this research was developed.

\subsection{Study Area}

The following report will follow a case study of six intersections located in Tillamook, Oregon. The City is located in western Tillamook County, on the southeast end of Tillamook Bay, and west of the Tillamook State Forest. Tillamook is located about 60 miles west of Portland and less than 10 miles from the Oregon coast. All six intersections are located along the US-101 couplet, which travels north-south through the City and provide connections from Tillamook to the communities of Garibaldi and Bay City to the north and Lincoln City to the south. The study intersections are shown in Figure 1 below, and are listed below:

- $\quad 3^{\text {rd }}$ Street / US $101 \mathrm{SB}$

- $3^{\text {rd }}$ Street / US $101 \mathrm{NB}$

- $4^{\text {th }}$ Street / US $101 \mathrm{SB}$

- $4^{\text {th }}$ Street / US $101 \mathrm{NB}$

- $11^{\text {th }}$ Street / US $101 \mathrm{SB}$

- $11^{\text {th }}$ Street / US $101 \mathrm{NB}$

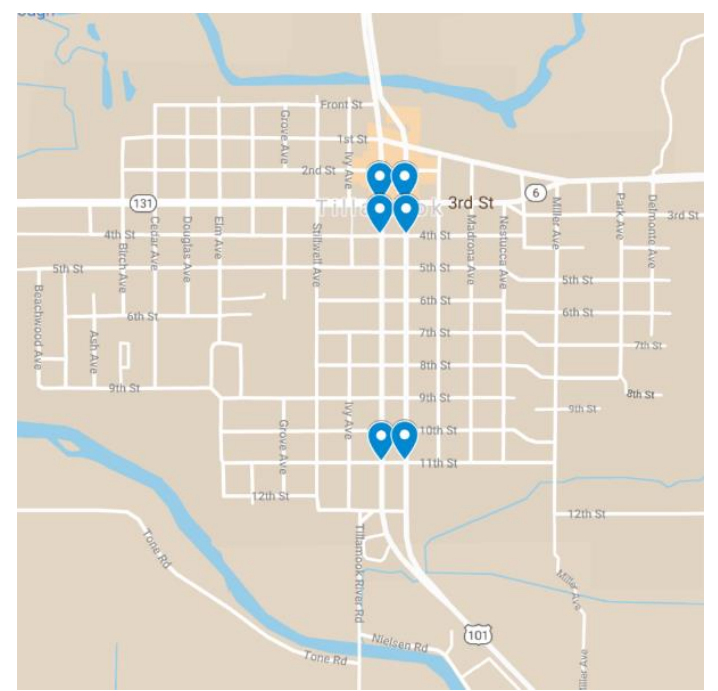

\section{Figure 1. Study Intersections in Tillamook, Oregon along US-101}

Study intersections for this research were chosen based upon available pedestrian and vehicle count data collected during the development of the recent update to Tillamook's Transportation System Plan, (TSP). As part of the project identification in the TSP update, a number of pedestrian crossings were evaluated and prioritized as a bundle for both basic and advanced crossing improvements. The purpose of this research is to provide a framework for how to prioritize crossings within these bundles to allocate funding to intersections that are experiencing the highest pedestrian risk. Notably, the intersections selected for this project were not necessarily identified by the TSP for improvement, but rather were chosen because of their differing infrastructure and exposure characteristics to show how risk estimation methods scoring impacts a variety of intersections.

The intersections on $3^{\text {rd }}$ Street and $4^{\text {th }}$ Street are located in what is known as "downtown" Tillamook, and are surrounded by grocery stores, restaurants, and shops. Each of these 
intersections is four-way stop controlled, with marked crosswalks on each leg. Importantly, during the time of the development of the TSP when pedestrian and vehicle counts were taken as well as the available crash data that was analyzed, the intersection of $4^{\text {th }}$ Street and US $101 \mathrm{SB}$ was under construction. To account for the construction's impact on data collected, the intersection was analyzed with only two marked crosswalks as the other two were under construction.

The intersections on $11^{\text {th }}$ Street are surrounded by single-family homes. Each intersection is fourleg stop controlled and may experience different crossing patterns and characteristics. Crosswalks are marked on at least two of the legs at each intersection, however the crosswalks are not clearly marked.

\subsection{Pedestrian Counts and Factoring Method}

Four-hour pedestrian counts were collected during the PM peak hours at each of the study intersections during the development of the City's TSP. ${ }^{1}$ According to methodology developed by the National Bicycle and Pedestrian Documentation Project, the peak hour was calculated at each intersection and counts were extrapolated to daily, monthly, and annual pedestrians. ${ }^{2}$ Table 1 summarizes each step that was taken to factor the peak hour counts at each intersection. Table 2 provides a summary of the peak hour pedestrian counts at each intersection and the AADT values that were calculated.

Table 1. Peak Hour Count Factoring Process

\begin{tabular}{|c|c|l|c|}
\hline Step & \multicolumn{1}{|c|}{ Name } & Description & Factor Applied \\
\hline $\mathbf{1}$ & Adjustment Factor & Reflection of non-peak pedestrians & Factored peak / 0.08 \\
\hline $\mathbf{2}$ & Average Weekday & $\begin{array}{l}\text { Hourly Adjustment Factor for weekday } \\
\text { pedestrian environment (4-5pm) }\end{array}$ & Average Weekday / 0.13 \\
\hline $\mathbf{3}$ & Average Weekly & Daily Adjustment Factors for Tuesday & Average Weekly $* 4.33$ \\
\hline $\mathbf{4}$ & Average Monthly & Average number of weeks in a month & Average Monthly / 0.08 \\
\hline $\mathbf{5}$ & Annual Totals & $\begin{array}{l}\text { Monthly Adjustment by Climate Area (June, } \\
\text { Moderate Climate) }\end{array}$ & Annual totals / 365 \\
\hline $\mathbf{6}$ & $\begin{array}{c}\text { Daily Averages } \\
\text { (AADT) }\end{array}$ & \begin{tabular}{l} 
365 days in a year \\
\hline
\end{tabular}
\end{tabular}

Table 2. Study Intersection Peak Hour Pedestrian Volumes

\begin{tabular}{|c|c|c|}
\hline Intersection & $\begin{array}{c}\text { Pedestrian Peak Hour } \\
\text { Count }\end{array}$ & $\begin{array}{c}\text { Pedestrian AADT } \\
\text { Value }\end{array}$ \\
\hline 3rd Street / US 101 SB & 220 & 793 \\
\hline 3rd Street / US 101 NB & 193 & 793 \\
\hline 4th Street / US 101 SB & 193 & 958 \\
\hline 4th Street / US 101 NB & 126 & 719 \\
\hline 11th Street / US 101 SB & 23 & 90 \\
\hline 11th Street / US 101 NB & 24 & 150 \\
\hline
\end{tabular}

${ }^{1}$ Counts were collected August 29, 2017 from 2-6pm.

${ }^{2}$ Count Adjustment Factors, National Bicycle \& Pedestrian Documentation Project, March 2009. 
These factors may not accurately represent pedestrian AADT in Tillamook, OR because pedestrian variations throughout the country are unknown and lack year-long automatic count data for adjustments. To control for this potential over or under-estimation, the same factored pedestrian counts will be used in each of the risk estimation methods.

\subsection{Brief Crash Data Analysis}

To understand the current state of pedestrian safety in Tillamook, the most recent available crash data (2013-2017) was obtained from ODOT's Crash Database. Eleven (11) pedestrian crashes occurred in Tillamook during the analysis period with five occurring at the study intersections excluding $4^{\text {th }}$ Street and US 101 NB. One serious injury occurred at $4^{\text {th }}$ Street and US 101 SB, and all crashes included at least one injured pedestrian. Although so few crashes occurred in the five-year analysis period, crashes that involve pedestrians are particularly concerning because of how vulnerable pedestrians are and how severe vehicle-pedestrian crashes can be. Because of this concern, other methods have been developed to quantify the safety of pedestrians besides crashes.

\subsection{Quantifying Pedestrian Risk}

As mentioned in the previous section, using crash data and frequency-based methods alone may not reveal where true pedestrian safety issues lie within the transportation system. As an alternative, risk-based methods may provide additional pedestrian safety context by incorporating additional explanatory variables.

Contextually, risk is defined as a probability or threat of damage, injury, liability, loss, or any other negative occurrence that is caused by external or internal vulnerabilities, and that may be avoided through preemptive action. As shown by the risk matrix in Figure 2, the amount of risk can be interpreted as the probability of the outcome and potential severity of the outcome if the event occurs, (Berdica, 2002). 


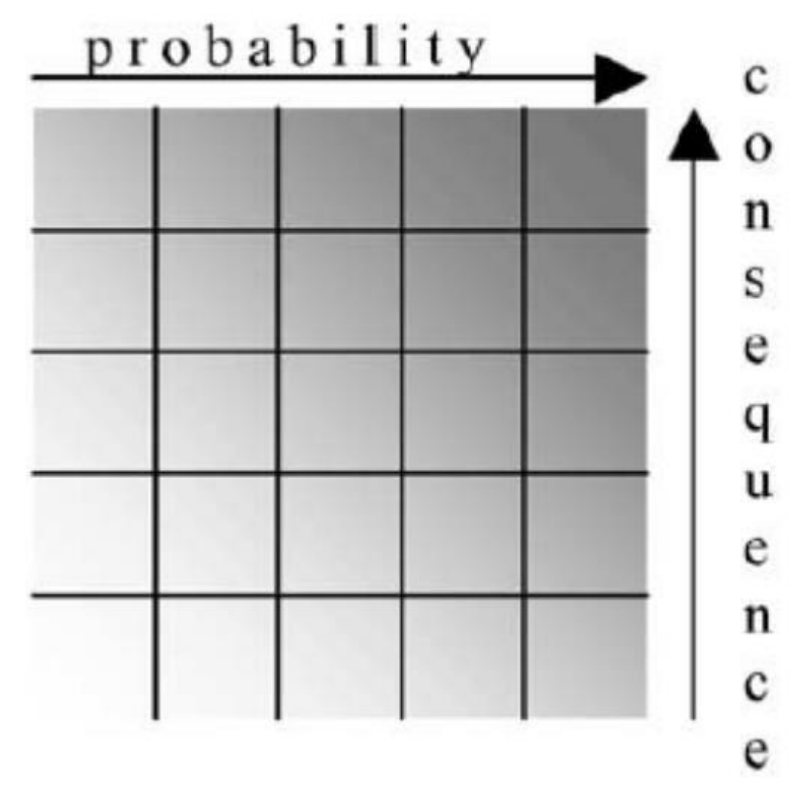

Figure 2. Risk Matrix, Darker Shading Indicates Higher Risk (Berdica, 2002)

For pedestrians, the probability of a crash is a function of exposure and the consequence is a function of the infrastructure or operating conditions. As the remainder of this report describes, risk-based scoring models include many different factors that increase risk levels for pedestrians that include elements of exposure and expectations of the severity of the outcome.

\subsection{ODOT SPR 779}

In an effort to mitigate both the rising number of pedestrian and bicycle fatalities and injuries throughout Oregon and the high social cost of these events, the Oregon Department of Transportation (ODOT) has identified pedestrian and bicycle crashes as a primary focus area for investing infrastructure funding, and subsequently has allocated approximately $\$ 4$ million annually in the All Roads Transportation Safety Program (ARTS) to help address this key need. Due to the low frequency of bicycle and pedestrian crashes, selecting and scheduling projects to address necessary safety concerns is challenging.

In conjunction with research teams from Portland State University (PSU), ODOT's State Planning and Research Program (SPR) developed pedestrian and bicycle risk-scoring methods with weights derived from data analysis in ODOT SPR 779. Prior risk-scoring methods at ODOT were developed using limited supplemental data and therefore risk scores were based on best judgement. This research greatly expanded the previous dataset by merging data elements that were collected on segments and intersections, and later developed into logistic models resulting in an easy to use tool. Inputs for the tool and a brief discussion on the methodology behind the tool will be described in the following chapter. The scope of this report limits discussion of ODOT's SPR 779 tool to only pedestrian risk-scoring methods at intersections. 


\subsection{FHWA SCRAM}

Similar to the motivation behind ODOT SPR 779, the FHWA recognizes that many transportation agencies are placing more emphasis on improving bicycle and pedestrian safety but are lacking a methodological approach to assess pedestrian and bicyclist risk for the purposes of identifying high-priority areas and transportation facilities for safety improvement. In conjunction with researchers from Texas A\&M Transportation Institute, University of Michigan Transportation Research Institute, and Kimley-Horn and Associates, Inc, the Federal Highway Administration (FHWA) developed a guide describing a scalable risk assessment method (SCRAM) for pedestrians and bicyclists which achieves the following items:

- Outlines eight sequential steps to develop risk values at various desired geographic scales.

- Describes the scope and nature of each step, including any guiding principles.

- Provides information on the analytic methods to estimate pedestrian and bicyclist exposure.

- Identifies other relevant guides and resources that provide supplemental information.

The guide is organized based on eight steps that can be followed to develop bicycle and pedestrian risk values at various geographic scales, shown in Figure 3. 


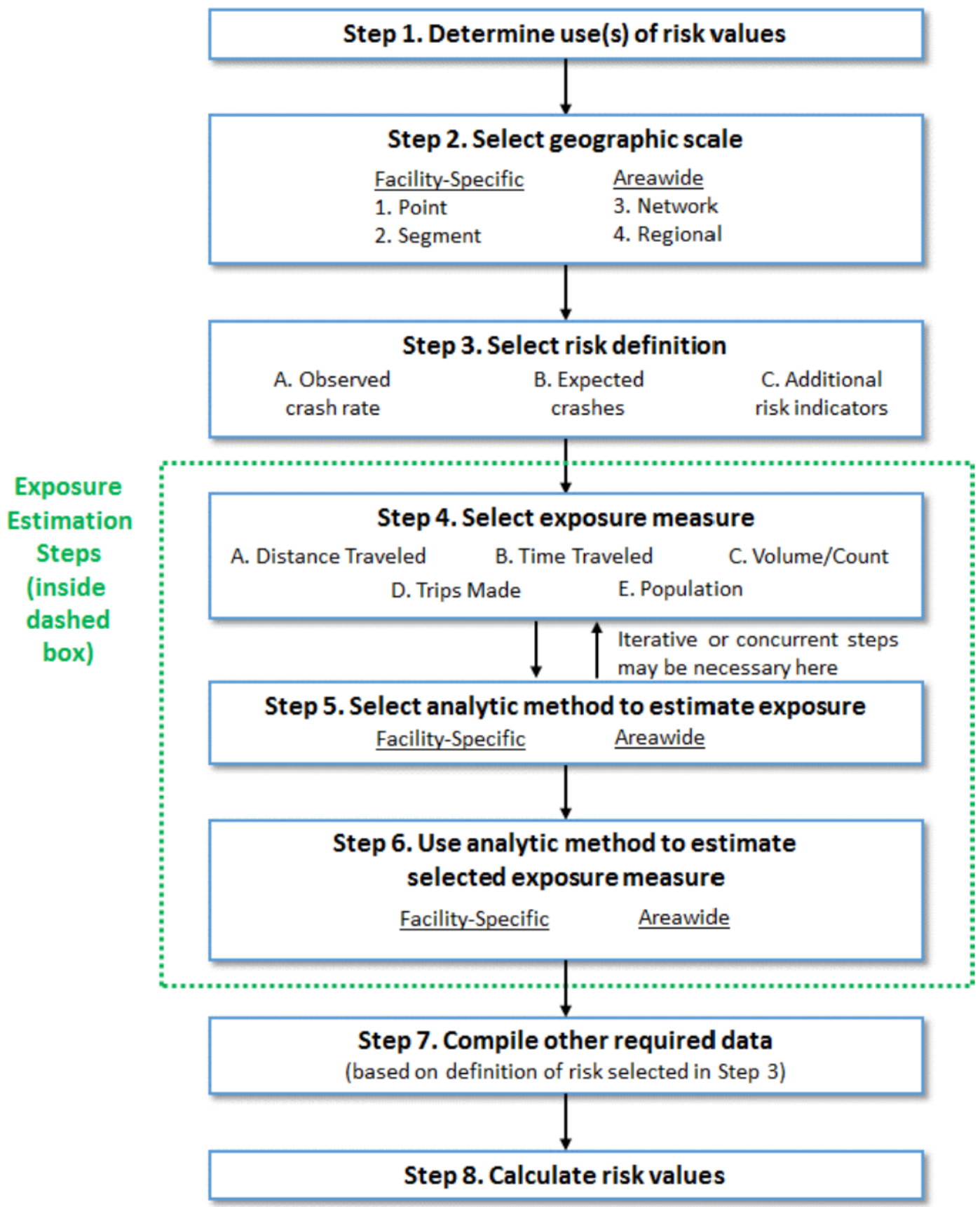

Figure 3. Eight Steps for Scalable Risk Assessment for Pedestrians and Bicyclists (SCRAM)

The methodology chapter will discuss each step in greater detail. Notably, the scope of this research is limited to evaluation of pedestrian risk only. 


\section{7 iRAP}

The International Road Assessment Programme (iRAP) is a United Kingdom based charity dedicated to saving lives through safer roads. Of particular interest for this research, iRAP works in partnership with government and non-government organizations throughout the world to inspect high-risk roads and develop star ratings and safer roads investment plans. Agencies across the world have adopted this program, including EuroRAP (European countries, mainly Sweden, Germany and the UK), AusRAP (Australia), usRAP (United States), and in New Zealand (KiwiRAP).

The program assigns star ratings and road safety scores to each road segment, which are based on the presence or absence of design and traffic control features known to be related to safety for both roadways and intersections. The star ratings range from one star to five stars, where one-star roads have the fewest safety-related design and traffic operational features and five-star roads have many safety-related design and traffic control features. Particularly applicable for this research, separate star ratings are assigned for vehicle occupants, motorcyclists, bicyclists, and pedestrians because the features that affect crash frequencies for the various travel modes differ substantially.

Via iRAP's website, free software and a global body of research that supports the predictive risk modeling program is available. Further details on the development of pedestrian specific risk models using iRAP will be discussed in the Methodology section of this report.

\subsection{HSM Predictive Models and Field Measured Exposure}

The Highway Safety Manual provides a predictive method for calculating the predicted and/or expected average crash frequency of a network, facility, or individual site through the concept of safety performance functions (SPFs). ${ }^{3}$ The resulting predictions of average crash frequency as a function of traffic volume and roadway characteristics can be used for making decisions related to designing, planning, operating, and maintaining roadway networks. The predictive method can be used to assess crashes for existing conditions, alternatives to existing conditions, or proposed new roadways.

For the purposes of this research, the predictive method was used to assess pedestrian type crashes for existing conditions at each of the study intersections. To relate the predictive model to the other risk assessment methods described in this report, the expected crash frequency determined by the HSM predictive models will be used with available exposure data to calculate pedestrian risk at each study intersection. Further details on the use of the HSM predictive model in this research will be provided in the Methodology section of this report.

${ }^{3}$ Highway Safety Manual, Part C: Predictive Method. 


\subsection{Field Measured Risk}

Historical crash data was used in conjunction with available exposure data to calculate a field measured risk value for each study intersection. Further detail on the calculation of exposure will be provided in the methodology section of this report. 


\subsection{METHODOLOGY}

The following chapter describes the methodology behind each risk estimation method and how it will be interpreted for this research.

\subsection{ODOT SPR 779}

In order to develop a useful risk-scoring tool with weights based on a detailed data analysis, the research team for ODOT SPR 779 identified a number of key risk factors for bicycle and pedestrian crashes. The risk factors are shown in Table 3.

\section{Table 3. Summary of Identified Risk Factors for Pedestrian Crashes}

\begin{tabular}{|c|c|c|}
\hline $\begin{array}{ll}\text { Roadway: } \\
\text { - } & \text { Average sidewalk width } \\
\text { - } & \text { Distance to the closest } \\
& \text { intersections } \\
\text { - } & \text { Lane widths } \\
\text { - } & \text { Maximum number of } \\
& \text { crossing stages } \\
\text { - } & \text { Number of driveways } \\
\text { - } & \text { Number of traffic } \\
& \text { directions } \\
\text { - } & \text { Number of traffic lanes } \\
\text { - } & \text { Paved shoulder } \\
\text { - } & \text { Presence of bus stop } \\
\text { - } & \text { crosence of marked } \\
\text { - Presence of median } & \text { Presence of paved } \\
& \text { sidewalk } \\
\text { - } & \text { Total road width }\end{array}$ & $\begin{array}{l}\text { Traffic Characteristics: } \\
\text { - } \quad \text { Average daily traffic } \\
\text { - } \quad \text { Functional class } \\
\text { - } \text { tumber of left- and right- } \\
\text { - } \text { Operating vehicles } \\
\text { - Pedestrian crossing } \\
\text { - } \quad \text { Polumes } \\
\text { - Percent heavy vehicles } \\
\text { - } \text { transit vehicles } \\
\text { - Posted speed limit } \\
\text { - Time of day } \\
\text { Weekend/weekday }\end{array}$ & 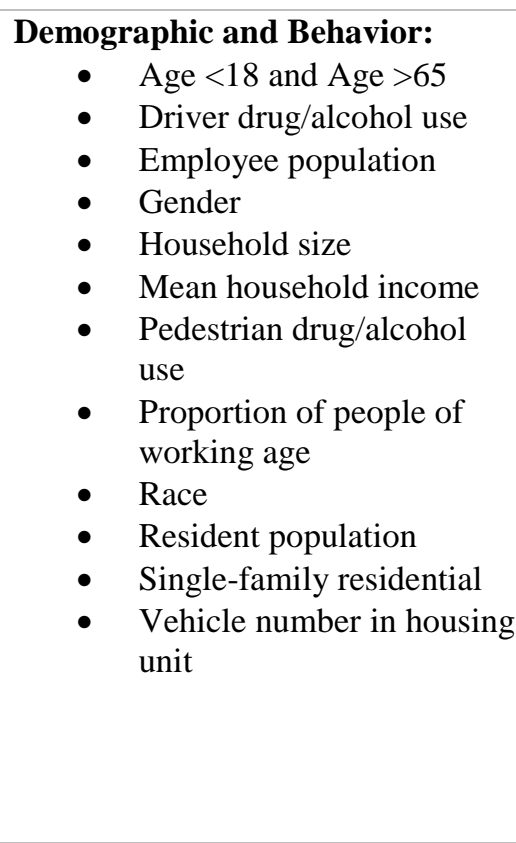 \\
\hline 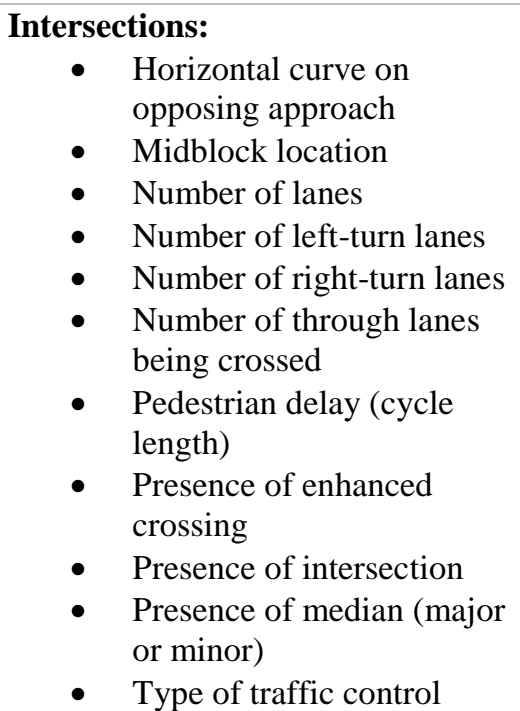 & $\begin{aligned} & \text { Land Use: } \\
& \text { - } \text { Block size } \\
& \text { - } \text { Natural resources } \\
& \text { inventory net density } \\
& \text { - } \text { Neighborhood business } \\
& \text { - } \text { Neighborhood service } \\
& \text { district } \\
& \text { - } \text { Residential-neighborhood } \\
& \text { commercial } \\
& \text { - } \text { Urban/rural areas }\end{aligned}$ & $\begin{array}{l}\text { Lighting and Weather: } \\
\text { - Lighting (Dark/daylight) } \\
\text { - Lighting adequacy data } \\
\text { - Visibility } \\
\text { - Weather } \\
\quad \text { (Clear/other/raining) }\end{array}$ \\
\hline
\end{tabular}


Multiple crash occurrence models were developed and tested, and the research team ultimately selected a logit occurrence model (crash/no crash) to develop risk scores. As risk is defined by a probability or threat of damage, injury, liability, loss, or any other negative occurrence that is caused by external or internal vulnerabilities that may be avoided through preemptive actions, risk scores include both elements of exposure and likely outcomes. The maximum risk score is set to 100 for the scoring matrix. Model results were converted to a risk score using the odds ratio, where a higher odds ratio indicates that there is a higher probability of having crashes. The base condition was transformed to the minimum odds ratio to make all scores positive, and each variable was assigned a component of the risk score based on the overall contribution.

Six variables were determined significant in calculations for risk scores for pedestrians at intersections, as shown in Table 4 . The largest contributing variable to the risk score was assigned to the number of transit routes running through the intersection (maximum weight $=$ 25). Population density in the census block received the next highest weight $($ maximum weight $=$ 21 ), followed by traffic volume with respect to major road AADT ( maximum weight $=18$ ), medians on the major roads (maximum weight $=13$ ), right-turn lanes on the minor roads ( maximum weight $=15)$, and right-turn lanes on the minor roads $($ maximum weight $=8)$. 
Table 4. Pedestrian Intersection Risk Scores

\begin{tabular}{|c|c|c|c|}
\hline Variable & Levels & Internal Weight & Risk Score \\
\hline \multirow{5}{*}{$\begin{array}{l}\text { Number of transit lines with routes through } \\
\text { intersection }\end{array}$} & 0 (base) & 1.00 & 0 \\
\hline & 1 & 1.47 & 6 \\
\hline & 2 & 2.15 & 8 \\
\hline & 3 & 3.16 & 12 \\
\hline & $>3$ & 6.79 & 25 \\
\hline \multirow[t]{5}{*}{ Total Population Density (per square mile) } & $<=1000$ & 1.00 & 0 \\
\hline & $(1001,3000)$ & 1.44 & 5 \\
\hline & $(3001,5000)$ & 2.30 & 8 \\
\hline & $(5001,7000)$ & 3.77 & 13 \\
\hline & $>7000$ & 6.03 & 21 \\
\hline \multirow[t]{6}{*}{ Major AADT (2014) } & $<=5000$ & 1.00 & 0 \\
\hline & $(5001,10000)$ & 1.37 & 5 \\
\hline & $(10001,15000)$ & 1.88 & 7 \\
\hline & $(15001,20000)$ & 2.57 & 10 \\
\hline & $(20001,25000)$ & 3.52 & 13 \\
\hline & $>25000$ & 4.82 & 18 \\
\hline \multirow[t]{2}{*}{ Minor road, presence of right-turn lanes } & Yes & 1.00 & 0 \\
\hline & No & 3.71 & 15 \\
\hline \multirow{2}{*}{ Presence of median on major road } & Yes & 1.00 & 0 \\
\hline & No & 3.52 & 13 \\
\hline \multirow[t]{2}{*}{ Major road, presence of right-turn lanes } & No & 1.00 & 0 \\
\hline & Yes & 2.19 & 8 \\
\hline
\end{tabular}

An Excel spreadsheet was constructed to aid the implementation of the risk scoring table. Notably, the risk scores are only intended to be evaluated within each context (i.e., the risk scores for pedestrians at intersections are not comparable for the risk scores for pedestrians on segments).

\subsection{FHWA SCRAM}

The following section will discuss each step of the SCRAM process for pedestrians and how it was interpreted for the purposes of this research. 


\section{Step 1. Determine Use of Risk Values}

The first step in developing risk values for pedestrians is to clearly define the use of the risk values. The use of the risk values provides direction throughout the remaining steps of the SCRAM process, and the guide provides several questions to help clarify the use and objective of each risk value. Typical uses of pedestrian risk values include:

- Safety Performance Measures

- Network Screening, both area-based and facility-based

- Countermeasure evaluation

- Site evaluation

- Project Prioritization

Figure 4 describes how determination of the use of risk values will impact the remaining steps in the SCRAM process.

\begin{tabular}{|c|c|c|c|c|c|c|c|c|c|c|c|c|c|c|c|}
\hline \multirow[t]{2}{*}{ Step 1. Define Use(s) of Risk Values } & \multicolumn{4}{|c|}{$\begin{array}{c}\text { Step 2. Select } \\
\text { Geographic Scale }\end{array}$} & \multicolumn{3}{|c|}{$\begin{array}{l}\text { Step 3. Select } \\
\text { Risk Definition }\end{array}$} & \multicolumn{5}{|c|}{$\begin{array}{l}\text { Step 4. Select Exposure } \\
\text { Measure }\end{array}$} & \multicolumn{3}{|c|}{$\begin{array}{l}\text { Step 5. Select } \\
\text { Analytic Method }\end{array}$} \\
\hline & $\stackrel{. \check{0}}{\circ}$ & 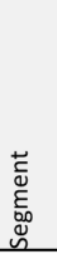 & $\begin{array}{l}\text { ㄴ. } \\
\vdots \\
\sum_{0}^{0} \\
z\end{array}$ & 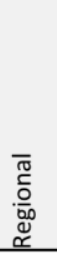 & 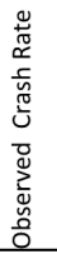 & 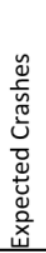 & 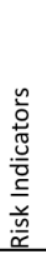 & 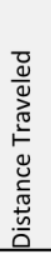 & 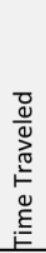 & 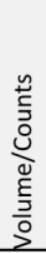 & 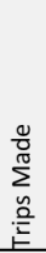 & $\begin{array}{l}\frac{1}{+0} \\
\frac{\pi}{3} \\
\frac{0}{0} \\
0\end{array}$ & 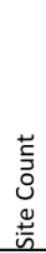 & 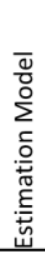 & 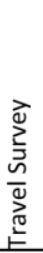 \\
\hline $\begin{array}{l}\text { Safety performance measures: } \\
\text { Track changes in risk over time }\end{array}$ & $\mathrm{x}$ & $x$ & $\checkmark$ & $\checkmark$ & $\checkmark$ & $x$ & $x$ & $\checkmark$ & $\checkmark$ & $\mathrm{x}$ & 0 & 0 & 0 & $x$ & $\checkmark$ \\
\hline $\begin{array}{l}\text { Network screening: area-based: } \\
\text { Identify high-risk areas for possible } \\
\text { improvement }\end{array}$ & NA & NA & $\checkmark$ & $\checkmark$ & $\checkmark$ & 0 & 0 & $\checkmark$ & $\checkmark$ & $x$ & 0 & 0 & $x$ & 0 & $\checkmark$ \\
\hline $\begin{array}{l}\text { Network screening: facility-based: } \\
\text { Identify high-risk facilities for possible } \\
\text { improvement }\end{array}$ & $\checkmark$ & $\checkmark$ & NA & NA & $\checkmark$ & 0 & 0 & 0 & 0 & $\checkmark$ & 0 & 0 & $\checkmark$ & $\checkmark$ & $x$ \\
\hline $\begin{array}{l}\text { Project prioritization: } \\
\text { Rank projects based on existing risk or } \\
\text { expected risk reduction }\end{array}$ & $\checkmark$ & $\checkmark$ & 0 & 0 & $\checkmark$ & 0 & $\checkmark$ & 0 & 0 & $\checkmark$ & $x$ & $x$ & $\checkmark$ & $\checkmark$ & $x$ \\
\hline $\begin{array}{l}\text { Countermeasure evaluation: } \\
\text { Evaluate if a specific countermeasure } \\
\text { reduces risk (and by how much) }\end{array}$ & $\checkmark$ & $\checkmark$ & NA & NA & $\checkmark$ & 0 & 0 & 0 & 0 & $\checkmark$ & $x$ & $x$ & $\checkmark$ & 0 & $x$ \\
\hline $\begin{array}{l}\text { Site evaluation: } \\
\text { Evaluate if risk was reduced after site } \\
\text { improvements (and by how much) }\end{array}$ & $\checkmark$ & $\checkmark$ & NA & NA & $\checkmark$ & $\checkmark$ & 0 & 0 & 0 & $\checkmark$ & $x$ & $x$ & $\checkmark$ & 0 & $x$ \\
\hline
\end{tabular}

Legend: $\checkmark=$ Yes, preferred; $O=$ yes, as a secondary preference; $X=$ Not likely; NA = Not applicable

\section{Figure 4. Selecting Key Parameters Based on Use(s) of Risk Values}

This research will estimate risk values for the purposes of project prioritization, so that it can easily be compared to other risk estimation methods that are geared towards similar outputs. The result of the SCRAM method will be a ranking of intersections based on their risk estimations. 


\section{Step 2. Select Geographic Scale}

Step 2 in the SCRAM process is to select the geographic scale at which risk and exposure values are desired. As mentioned previously, the use of the risk value will often help define the geographic scale. Subsequently, the selection of geographic scale will impact the remainder of the steps in this process. The four scale categories in the Scalable Risk Assessment process are shown in Table 5.

\section{Table 5. Four Scale Categories in the Scalable Risk Assessment Process}

\begin{tabular}{|c|c|c|c|}
\hline Scale Group & Scale Category & Description & Examples \\
\hline \multirow[t]{2}{*}{ Facility-Specific } & Point & $\begin{array}{l}\text { Specific location where } \\
\text { conflicting traffic streams cross, } \\
\text { merge, or diverge. }\end{array}$ & $\begin{array}{l}\text { - Single intersection or mid- } \\
\text { block crossing } \\
\text { - All crossings at an } \\
\text { intersection } \\
\text { - Conflict zone (e.g., merge } \\
\text { area) }\end{array}$ \\
\hline & Segment & $\begin{array}{l}\text { Length of street or roadway } \\
\text { between two points. Traffic } \\
\text { volumes and physical } \\
\text { characteristics generally remain } \\
\text { the same along the length of a } \\
\text { segment, although very small } \\
\text { variations occur. }\end{array}$ & $\begin{array}{l}\text { - Street segment between } \\
\text { major intersections } \\
\text { Multiple street segments } \\
\text { along a single facility, or on } \\
\text { parallel facilities (e.g., } \\
\text { corridor) } \\
\text { - Street segment of defined } \\
\text { length (e.g., one mile) }\end{array}$ \\
\hline \multirow[t]{2}{*}{ Areawide } & Network & $\begin{array}{l}\text { A mid-sized geographic area that } \\
\text { includes an interconnected set of } \\
\text { transportation facilities. }\end{array}$ & $\begin{array}{ll}\text { - } & \text { Census tracts } \\
\text { - } & \text { Census block groups } \\
\text { - } & \text { Traffic analysis zones } \\
\end{array}$ \\
\hline & Regional & $\begin{array}{l}\text { A large geographic area that } \\
\text { includes all transportation } \\
\text { facilities within a defined } \\
\text { political boundary. Because of } \\
\text { the large geographic size, land } \\
\text { use at this scale can be } \\
\text { heterogeneous within a defined } \\
\text { area. }\end{array}$ & $\begin{array}{ll}\text { - } & \text { City } \\
\text { - } & \text { County } \\
\text { - } & \text { Metropolitan Statistical } \\
& \text { Area } \\
\text { - } & \text { State }\end{array}$ \\
\hline
\end{tabular}

This research will analyze the six study intersections as facility-specific points. 


\section{Step 3. Select Risk Definition}

Step 3 in the SCRAM process is to select a specific definition of risk that will be used to calculate quantitative risk values. Table 6 describes the possible definitions for pedestrian risk.

Table 6. Possible Definitions of Pedestrian Risk

\begin{tabular}{|c|c|c|c|}
\hline & 1. Observed Crash Rate & 2. Expected Crashes & 3. Additional Risk Indicators \\
\hline Description & $\begin{array}{ll} & \text { Risk }=\text { Observed } \\
\text { crashes divided by } \\
\text { exposure } \\
\text { Obtain observed } \\
\text { crashes from } \\
\text { available crash } \\
\text { database(s). } \\
\text { - Estimate exposure } \\
\text { with the guide. }\end{array}$ & 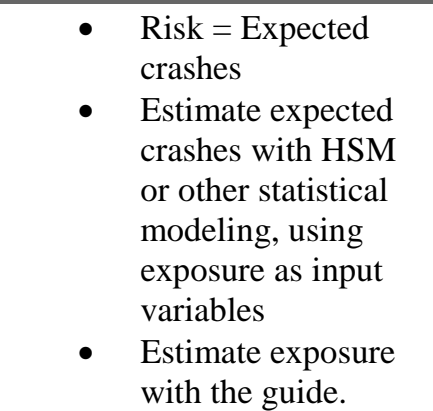 & $\begin{array}{l}\text { Risk }=\text { function of one } \\
\text { or more risk } \\
\text { indicators: observed } \\
\text { crashes, facility type } \\
\text { or condition, motor } \\
\text { vehicle speed and } \\
\text { volume, adjacent land } \\
\text { use, exposure, etc. } \\
\text { Estimate exposure } \\
\text { with the guide. }\end{array}$ \\
\hline Strengths & $\begin{array}{l}\text { Common use among } \\
\text { many practitioners. } \\
\text { Use with other crash } \\
\text { analysis tools. }\end{array}$ & $\begin{array}{l}\text { Use of expected } \\
\text { crashes overcomes } \\
\text { issues with low (or } \\
\text { no) observed crash } \\
\text { frequency. } \\
\text { Permits evaluation } \\
\text { of implemented } \\
\text { countermeasures. }\end{array}$ & $\begin{array}{ll} & \text { Compatible with } \\
\text { FHWA Systemic } \\
\text { Safety Analysis. } \\
\text { - Approach geared } \\
\text { towards practitioners. }\end{array}$ \\
\hline Limitations & $\begin{array}{l}\text { Low exposure or low } \\
\text { (or no) frequency of } \\
\text { observed crashes may } \\
\text { not accurately } \\
\text { represent risk }\end{array}$ & $\begin{array}{l}\text { Requires advanced } \\
\text { statistical methods } \\
\text { to estimate expected } \\
\text { crashes. }\end{array}$ & $\begin{array}{l}\text { - Risk is a } \\
\text { dimensionless } \\
\text { numeric score or } \\
\text { rating, not a crash } \\
\text { frequency or crash } \\
\text { value. }\end{array}$ \\
\hline
\end{tabular}

This research will define risk within the SCRAM process by using more than one risk indicator combined into a composite risk score. Additional risk factors will be determined through a Systemic Safety Analysis and discussed in further detail in the analysis section of this report. The limitations of this method will be addressed by the other risk estimation methods within this research.

\section{Step 4. Select Exposure Measure}

Step 4 in the SCRAM process is to select a specific exposure measure to be used in the calculation of risk values. There are several different categories of exposure measures that attempt to quantify the level of contact that pedestrians have with potentially harmful safety outcomes; however, the following five exposure measures are included in the SCRAM guidance:

- Distance Traveled - cumulative distance traveled by all pedestrians at the specified geographic scale, most commonly measured as pedestrian miles traveled (PMT).

- Time Traveled - cumulative time traveled by all pedestrians at the specified geographic scale, most commonly measured as pedestrian hours traveled. 
- Volume/Count - number of pedestrians for a specified time period and geographic scale, which sometimes may be annualized for a typical day.

- Trips Made - cumulative number of trips made by all pedestrians at the specified geographic scale.

- Population - number of people (or specified sub-population) at the specified geographic scale, most commonly measured as the number of people (or percent of the population) that walk.

Figure 5 shows the selection matrix provided by the SCRAM guide, which recommends exposure measures based on the appropriate geographic scale that was selected in Step 3.

\begin{tabular}{|c|c|c|c|c|c|c|}
\hline \multirow{2}{*}{$\begin{array}{l}\text { Category of } \\
\text { Exposure } \\
\text { Measure }\end{array}$} & \multirow{2}{*}{ Typical measures } & \multicolumn{4}{|c|}{ Typical scale } & \multirow{2}{*}{ Typical data sources } \\
\hline & & Point & Segment & Network & Region & \\
\hline \multirow[b]{2}{*}{$\begin{array}{l}\text { Distance } \\
\text { Traveled }\end{array}$} & Miles of travel & & & & & \multirow{2}{*}{ 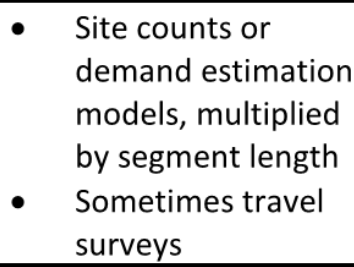 } \\
\hline & $\begin{array}{l}\text { Miles crossed per } \\
\text { entering vehicle }\end{array}$ & & & & & \\
\hline \multirow[b]{2}{*}{$\begin{array}{l}\text { Time } \\
\text { Traveled }\end{array}$} & Hours of travel & & & & & \multirow{2}{*}{$\begin{array}{l}\text { - } \quad \text { Travel surveys } \\
\text { Sometimes site } \\
\text { counts combined } \\
\text { with crossing time } \\
\text { or average travel } \\
\text { speed data. }\end{array}$} \\
\hline & $\begin{array}{l}\text { Product of crossing } \\
\text { time and vehicle } \\
\text { volume }\end{array}$ & & & & & \\
\hline \multirow[b]{2}{*}{$\begin{array}{l}\text { Volume/ } \\
\text { Count }\end{array}$} & Volume/count & & & & & \multirow{2}{*}{$\begin{array}{ll}\text { - } & \text { Site counts } \\
\text { - } & \text { Demand } \\
& \text { estimation models }\end{array}$} \\
\hline & $\begin{array}{l}\text { Product of pedestrian } \\
\text { /bicyclist volumes and } \\
\text { motor vehicle volumes }\end{array}$ & & & & & \\
\hline Trips Made & Number of trips & & & & & - $\quad$ Travel surveys \\
\hline \multirow{2}{*}{ Population } & $\begin{array}{c}\text { Number of people that } \\
\text { walk or cycle on regular } \\
\text { basis }\end{array}$ & & & & & \multirow[t]{2}{*}{$\begin{array}{l}\text { - U.S. Census data } \\
\text { products }\end{array}$} \\
\hline & $\begin{array}{l}\text { Percent of the } \\
\text { population that walk or } \\
\text { cycle on regular basis }\end{array}$ & & & & & \\
\hline
\end{tabular}

Legend: $\bigcirc$ = to a small extent; $D=$ to a moderate extent; $O$ = to a great extent.

Note: Each exposure measure will be for a defined time period that matches the risk definition.

\section{Figure 5. Selection Matrix for Exposure Measures}

This research selected pedestrian volume/counts as the exposure method for the Scalable Risk Assessment. The strength of this selection aside from it matching with the appropriate geographic scale, is that no assumptions will be made about distance or time traveled that are required in the other recommended exposure measures for a point scale. 
In the development of the recently adopted Tillamook Transportation System Plan (TSP), fourhour weekday PM peak hour (2-6pm) intersection counts were collected at the identified study intersections. ${ }^{4}$ Counts were then factored to average daily numbers following methodology developed by the National Bicycle and Pedestrian Documentation Project. ${ }^{5}$ The pedestrian average daily numbers were then multiplied by vehicle $\mathrm{AADT}^{6}$ to estimate exposure at each intersection with the following equation:

$$
\text { Pedestrian Volume } * \text { Motor Vehicle Volume }=\text { Pedestrian Exposure }
$$

Documentation of pedestrian count factoring and exposure calculations can be found in the Background section of this report.

\section{Step 5. Select Analytic Method to Estimate Exposure}

Step 5 in the SCRAM process is to select an analytic method to exposure. There are numerous analytic methods that can be used to estimate exposure that depend on the desired geographic scale, scope, data availability, and available analysis resources. The analytic methods outlined in the guide include:

\section{- Site counts}

- Demand estimation models

- Direct demand models

- Regional TDM

- Trip generation and flow models

- GIS-based models

- Discrete choice models

- Simulation-based traffic models

- Data fusion

- Travel Surveys
○ ACS
○ NHTS
○ Regional household travel survey

For this research, site counts were selected to estimate exposure. Other analytic methods require additional steps for estimating exposure, however the methodology used to translate individual site counts to pedestrian exposure at each intersection was described in the previous step.

\section{Step 6. Use Analytic Method to Estimate Selected Exposure Measure}

Step 6 in the SCRAM process is to use the analytic method selected in step 5 to estimate the desired exposure measure. Within the SCRAM guide, step 6 provides an overview of the manual

\footnotetext{
${ }^{4}$ Counts collected on August 29, 2017 from 2-6pm.

${ }^{5}$ Count Adjustment Factors, National Bicycle and Pedestrian Documentation Project, March 2009.

${ }^{6}$ Major roadway AADT obtained from the ODOT TransGIS Database, Minor Roadway AADT calculated from intersection turning movement counts collected for the Tillamook TSP on August 29, 2017.
} 
and automated counting procedures that could be used to estimate selected exposure. These methods were not used in this research, as recent count data was available.

\section{Step 7. Compile Other Required Data}

Step 7 in the SCRAM process consists of compiling other data besides exposure that is required based upon the risk definition selected in Step 3. Where this research had less involvement in step 5 and step 6 of the SCRAM process, step 7 involved a much more detailed analysis.

A Systemic Safety Approach was used to develop a list of additional risk factors. ${ }^{7}$ A review of the attributes from the crash data analysis and roadway inventory to determine which risk factors were present at one or more of the study intersections. Table 7 describes the risk indicators that were identified, and the appropriate thresholds based on the conditions of intersections throughout the City of Tillamook.

Table 7. Identified Risk Indicators

\begin{tabular}{|l|l|}
\hline Risk Indicator & Risk Threshold \\
\hline Minor Approach Functional Class & Urban Collector and above \\
\hline Traffic Control & Presence of a traffic signal \\
\hline Presence/Proximity of a Transit Stop & Bus stop within 500 feet of intersection \\
\hline Volume & \begin{tabular}{l} 
Major Roadway AADT over 6500 \\
\hline Exposure
\end{tabular} \\
$\begin{array}{l}\text { Exposure value within top 50\% of intersections with } \\
\text { available data in Tillamook }\end{array}$ \\
\hline
\end{tabular}

Outputs of each risk indicator at the study intersections are documented in the analysis section of this report.

\section{Step 8. Calculate Risk Values}

Step 8 in the SCRAM process is to calculate risk values based on the outputs from the previous steps. For project prioritization purposes, this research used the defined risk thresholds to assign one "star" to an intersection if it exhibited conditions above the risk threshold. Therefore, intersections with a higher number of stars are presumably more risky intersections and should be prioritized for safety improvements. Star ratings and risk values are documented in the analysis section of this report.

\section{3 iRAP}

The iRAP methodology involves combining a decided upon number of risk factors to develop an overall risk score. These risk factors are equitable to crash modification factors (CMFs), which are used to compute the expected number of crashes after implementing a given countermeasure at a specific site. In general, iRAP follows a multiplicative model for each of its factors:

$$
\text { Risk Score }=\text { likelihoodfactor } * \text { likelihood factor } * \text { likelihood factor }
$$

\footnotetext{
${ }^{7}$ Methodology provided by the Systemic Safety Project Selection Tool promoted by the FHWA.
} 
Agencies may choose to include other factors such as protection actors or area accident type factors, however this research only included likelihood factors based on available data.

Risk factor definitions and scores that are used in iRAP products are available on their website in the form of fact sheets, however the selection of criteria for a specific crash type is dependent on the agency. For the purposes of this research, framework for determining which risk factors should be included in the pedestrian risk models was chosen based on the EuroRAP rating process to provide an additional layer of context outside of the United States for comparing risk estimation methods. The factors included in the EuroRAP pedestrian model are shown in Table 8.

Table 8. Factors included in the EuroRAP Pedestrian Model

\begin{tabular}{|l|l|l|}
\hline Mode & Accident Type & Likelihood Factor \\
\hline Pedestrian & Along Road & Speed \\
& & Sidewalk \\
& Crossing & Side Friction \\
\cline { 2 - 3 } & & Speed \\
& & Number of Lanes \\
& & Median Type \\
& & Pedestrian Crossing Facilities \\
& & Quality of Crossing \\
\hline
\end{tabular}

For the purposes of this research, the likelihood factors for the Crossing accident type were selected for the risk estimation model. After consideration of the EuroRAP factors and a review of the remaining factors applicable to pedestrians, the following attributes were selected for the iRAP risk estimation model:

- Speed (mph)

- Number of Lanes

- Pedestrian Crossing Facilities

- Quality of Crossing

- Intersection Type

- Vehicle Parking

Notably, "Median Type" was removed from the final list of likelihood factors because all study intersections are located on one-way roadways with no presence of a median. Table 9 describes each road attribute risk and its associated likelihood factor. Notably, only relevant categories for the study intersections were included in this table, and additional categories can be found on the iRAP fact sheets available on their website. The assumption was made that all study intersections are located in an urban area. 
Table 9. iRAP Risk Factor Key

\begin{tabular}{|c|c|c|}
\hline Road Attribute & Category & Risk Factor (Urban) \\
\hline \multirow{2}{*}{ Operating Speed (mph) } & $<20$ & 0.01 \\
\hline & 25 & 0.019 \\
\hline \multirow{2}{*}{ Number of Lanes } & One & 1 \\
\hline & Two & 0.02 \\
\hline \multirow[b]{2}{*}{ Pedestrian Crossing Facility } & Signalized without refuge & 1.25 \\
\hline & $\begin{array}{l}\text { Unsignalized marked crossing } \\
\text { without refuge }\end{array}$ & 4.8 \\
\hline \multirow{3}{*}{ Quality of Crossing ${ }^{8}$} & Poor & 1.5 \\
\hline & Adequate & 1 \\
\hline & Not Applicable & 1 \\
\hline \multirow{3}{*}{ Intersection Type } & $\begin{array}{l}\text { 4-leg unsignalized without } \\
\text { protected turn lane }\end{array}$ & 70 \\
\hline & $\begin{array}{l}\text { 4-leg signalized without protected } \\
\text { turn lane }\end{array}$ & 45 \\
\hline & $\begin{array}{l}\text { 4-leg signalized with protected turn } \\
\text { lane }\end{array}$ & 35 \\
\hline \multirow{2}{*}{ Vehicle Parking } & One side & 1.2 \\
\hline & Two sides & 1.33 \\
\hline
\end{tabular}

All data necessary to assign each risk factor was obtained via Google Streetview. Risk score results for each intersection according to the iRAP scoring system are found in the Analysis section of this report. Noticeably, a likelihood factor of exposure has been excluded from the risk estimation with the iRAP method in this report. The iRAP methodology includes two likelihood factors related to pedestrian risk: pedestrian external flow and pedestrian observed flow.

Pedestrian external flow reflects risk to pedestrians increasing with the flow of heavier mass vehicles and motorcyclists at the location. The road attribute factors would be used to reflect the likelihood that a pedestrian would be struck by a vehicle. As shown in Figure 6 below, for the purposes of the iRAP model where the highest side road volume category is $>15,000(7,500$ vehicles per lane assuming a two-lane road) the peak value of 0.5 has been adopted for any intersecting road with lane flows greater than $7,500 .{ }^{9}$

\footnotetext{
${ }^{8}$ Quality of Crossing categories determined by iRAP handbook. Description of this road attribute can be found in iRAP Coding Manual as described in Reference List.

9 iRAP Model Factsheet 5 - External Flow.
} 
Figure 6. Pedestrian (crossing side road at intersection) external flow risk factors

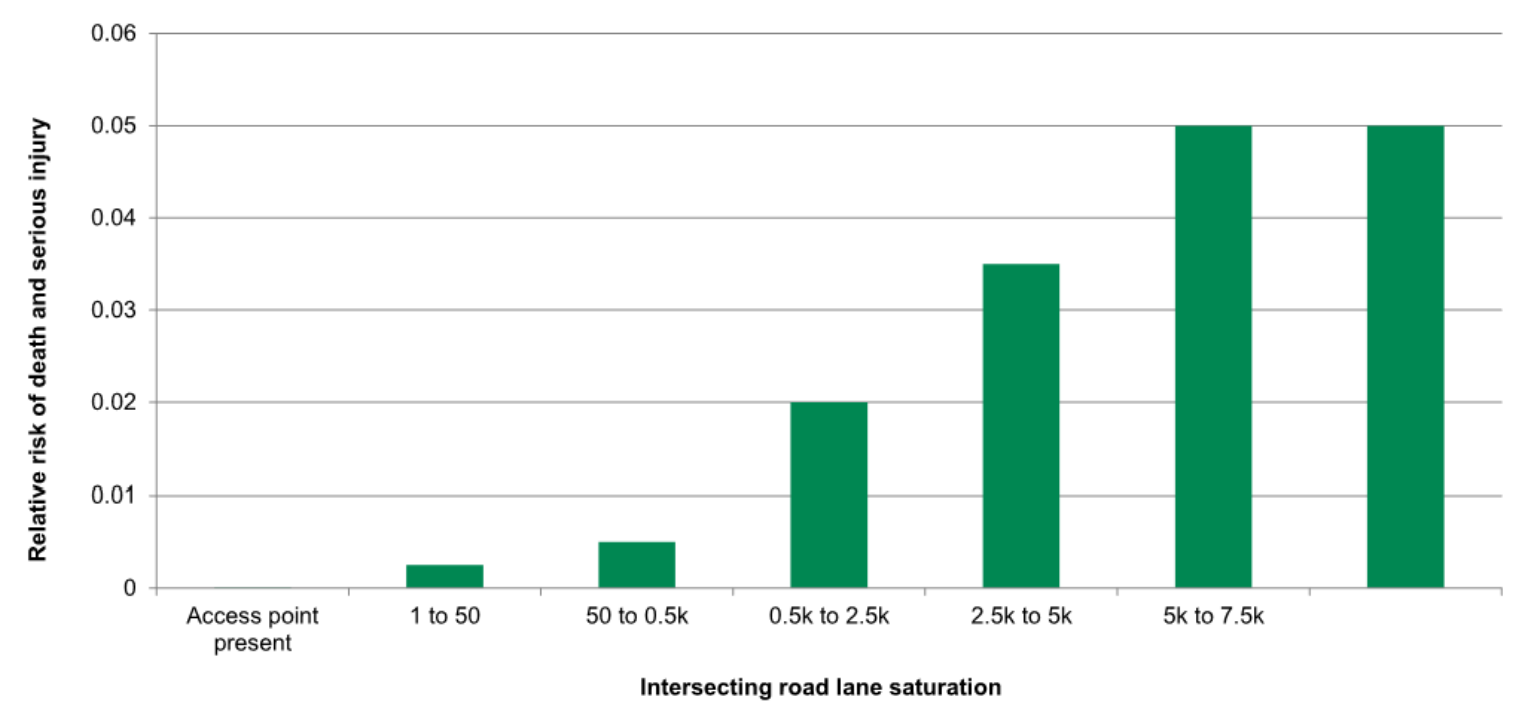

Due to the location of the study intersections on US-101 in this research, each study intersection received the same risk factor value for pedestrian external flow. Therefore, this likelihood factor was not included in the iRAP risk estimation for this report.

The pedestrian observed flow likelihood factor is expected to have had an impact on the overall risk estimation for the iRAP method. However, due to the proprietary nature of the iRAP methodology, not all risk factor values are available without full purchase of the program. For that reason, the pedestrian observed flow likelihood factor was not included in the iRAP risk estimation for this report.

\subsection{HSM Predictive Models and Field Measured Exposure}

The HSM Predictive Method can be used to assess crash frequencies of a network, facility, or individual site under existing conditions. The method focuses on the use of statistical models to address the inherent randomness of crashes and calculates expected and/or predicted crash frequencies based on roadway characteristics and traffic volume. There are three crash frequencies that can be used in the predictive method:

- Observed crash frequency - historical crash data observed/reported at the site during the period of analysis.

- Predicted average crash frequency - can be modeled with the geometric design, traffic control features, and traffic volumes of a site.

- Expected average crash frequency - the long-term average crash frequency that would be expected from the site, only used when observed crash frequency is available. 
The predictive models in HSM Part C are composed of three basic elements:

- Safety Performance Functions (SPFs)

- Crash Modification Factors (CMFs)

- Local calibration factors

The following formula shows how expected average crashes are estimated at signalized intersections ${ }^{10}$ :

Where:

$$
N_{\text {ped }}=N_{\text {pedbase }} \times C M F_{1 p} \times C M F_{2 p} \times C M F_{3 p}
$$

$N_{\text {ped }}=$ Esdtimated Number of Crashes

$N_{\text {pedbase }}=$ Number of Predicted Crashes according to SPF for Vehicle

$$
\text { - Pedestrian Collisions }
$$

$C M F_{p 1}, C M F_{p 2}, C M F_{p 3}=C M F s$ for Vehicle - Pedestrian Collisions

For pedestrian collisions that occur at stop-controlled intersections, overall crashes are multiplied by a Pedestrian Crash Adjustment Factor using the following equation and Table 10:

$$
N_{\text {ped }}=N_{\text {total }} \times f_{\text {pedi }}
$$

Table 10. Pedestrian Crash Adjustment Factors

\begin{tabular}{cc}
\hline Intersection Type & $\begin{array}{c}\text { Pedestrian Crash } \\
\text { Adjustment Factor }\left(\boldsymbol{f}_{\text {pedi }}\right)\end{array}$ \\
\hline 3ST & 0.021 \\
\hline 4ST & 0.022 \\
\hline
\end{tabular}

To calculate expected crash frequency, an additional step is added to incorporate the observed crash frequency by weighting with Empirical Bayes (EB). Table 11 describes the data requirements that are needed to complete the spreadsheet, which requires inputs for the SPFs, CMFs, Local Calibration Factors, and necessary elements for the EB Method.

Table 11. Pedestrian Data Needed for SPF Calculation

\begin{tabular}{l}
\hline Data Element \\
\hline Vehicle AADT \\
\hline Number of Lanes \\
\hline Pedestrian Volume \\
\hline Bus Stops within $1,000 \mathrm{ft}$ \\
\hline Number of Alcohol Sales Establishments \\
within $1,000 \mathrm{ft}$ \\
\hline Schools within $1,000 \mathrm{ft}$ \\
\hline
\end{tabular}

\footnotetext{
${ }^{10}$ Equation 12-28, Highway Safety Manual Urban-Suburban Equations.
} 
The remainder of this section will provide further detail for calculating the expected average number of pedestrian-vehicle crashes at signalized intersections.

Safety performance functions (SPFS) are used to estimate the predicted average crash frequency of an individual roadway segment or intersection. They are developed through statistical regression techniques using historical crash data collected over a number of years at "base" sites with similar characteristics. Particularly of interest for this research, for intersections the dependent variable is the predicted average crash frequency for a facility type under base conditions, and the independent variables are AADT on the major and minor roads. The SPFs are developed for total crash frequency including all crash severity levels and collision types, however SPFs for specific collision types and/or crash severity levels are also developed. Table 12 shows the appropriate SPFs for a given crash frequency at a specific site.

Table 12. List of SPFs by Facility Type

\begin{tabular}{|c|c|c|c|}
\hline $\begin{array}{l}\text { Facility Types } \\
\text { (HSM Chapter) }\end{array}$ & Facility Type & SPF for Collision Type & SPF for Crash Severity Level \\
\hline \multirow{2}{*}{$\begin{array}{l}\text { Rural Two-Lane, } \\
\text { Two-Way Roads } \\
\text { (Chapter 10) }\end{array}$} & Roadway Segment & All collision types & All severity levels \\
\hline & Intersection & All collision types & All severity levels \\
\hline \multirow{2}{*}{$\begin{array}{l}\text { Rural Multilane } \\
\text { Highways (Chapter } \\
\text { 11) }\end{array}$} & Roadway Segment & All collision types & $\begin{array}{l}\text { - All severity levels } \\
\text { - Fatal-and-injury crashes }\end{array}$ \\
\hline & Intersection & All collision types & $\begin{array}{l}\text { - All severity levels } \\
\text { - Fatal-and-injury crashes }\end{array}$ \\
\hline \multirow{10}{*}{$\begin{array}{l}\text { Urban and } \\
\text { Suburban } \\
\text { Arterials (Chapter } \\
\text { 12) }\end{array}$} & \multirow[t]{6}{*}{ Roadway Segment } & Single-vehicle collision & $\begin{array}{l}\text { - All severity levels } \\
\text { - Fatal-and-injury crashes } \\
\text { - PDO crashes }\end{array}$ \\
\hline & & $\begin{array}{l}\text { Multiple-vehicle non-driveway } \\
\text { collision }\end{array}$ & $\begin{array}{l}\text { - All severity levels } \\
\text { - Fatal-and-injury crashes } \\
\text { - PDO crashes }\end{array}$ \\
\hline & & Single-vehicle collision & All severity levels \\
\hline & & $\begin{array}{l}\text { Multiple-vehicle driveway- } \\
\text { related collision }\end{array}$ & All severity levels \\
\hline & & Vehicle-pedestrian collision & All severity levels \\
\hline & & Vehicle-bicycle collision & All severity levels \\
\hline & \multirow[t]{4}{*}{ Intersection } & Multiple-vehicle collision & $\begin{array}{l}\text { - All severity levels } \\
\text { - Fatal-and-injury crashes } \\
\text { - PDO crashes }\end{array}$ \\
\hline & & Single-vehicle collision & $\begin{array}{l}\text { - All severity levels } \\
\text { - Fatal-and-injury crashes } \\
\text { - PDO crashes }\end{array}$ \\
\hline & & Vehicle-pedestrian collision & All severity levels \\
\hline & & Vehicle-bicycle collision & All severity levels \\
\hline
\end{tabular}


The SPFs that will be used in this research are at Intersections on Urban and Suburban Arterials for vehicle-pedestrian collisions at all severity levels ${ }^{11}$ :

Where:

$$
\begin{aligned}
& N_{\text {pedbase }}= \exp \left(a+b \times \ln \left(A A D T_{\text {total }}\right)+c \times \ln \left(\frac{A A D T_{\text {min }}}{A A D T_{\text {maj }}}\right)+d \times \ln (\text { PedVol })\right. \\
&\left.+e \times n_{\text {lanes }}\right)
\end{aligned}
$$

$a, b, c, d, e=$ references from HCM Table $12-14$

$A A D T_{\text {total }}=$ total Annual Average Daily Traffic of both major and minor roadways

$A A D T_{\min }=$ total Annual Average Daily Traffic of minor roadway

$A A D T_{\text {maj }}=$ total Annual Average Daily Traffic of major roadway

PedVol = total Annual Average Daily Pedestrian Volume

$n_{\text {lanes }}=$ number of lanes

Table 13. SPFs for Vehicle-Pedestrian Collisions at Signalized Intersections (Table 12-14,

\begin{tabular}{|c|c|c|c|c|c|c|}
\hline \multirow[b]{2}{*}{$\begin{array}{c}\text { Intersection } \\
\text { Type }\end{array}$} & \multicolumn{5}{|c|}{ Coefficients Used in Equation 12-29 } & \multirow[b]{2}{*}{$\begin{array}{l}\text { Overdispersion } \\
\text { Parameter (k) }\end{array}$} \\
\hline & $\begin{array}{c}\text { Intercept } \\
\text { (a) }\end{array}$ & $\begin{array}{l}\mathrm{AADT}_{\text {total }} \\
\text { (b) }\end{array}$ & $\begin{array}{l}\mathrm{AADT}_{\text {min }} \\
/ \\
\mathrm{AADT}_{\text {max }} \\
\text { (c) }\end{array}$ & PedVol & $\mathrm{N}_{\text {lanes }}$ & \\
\hline \multicolumn{7}{|l|}{ Total Crashes } \\
\hline 3SG & -6.60 & 0.05 & 0.24 & 0.41 & 0.09 & 0.52 \\
\hline 4SG & -9.53 & 0.40 & 0.26 & 0.45 & 0.04 & 0.24 \\
\hline
\end{tabular}
HSM)

While the base models are calculated using a given set of site characteristics to calculate the predicted average crash frequency, Crash Modification Factors (CMFs) are used to adjust the base model to local conditions. A CMF represents the relative change in estimated average crash frequency due to differences for each specific condition. The following set of tables represent each CMF included in the vehicle-pedestrian collisions at signalized intersections where Table 14 describes $C M F_{1 p}$, Table 15 describes $C M F_{2 p}$, and Table 16 describes $C M F_{3 p}$.

${ }^{11}$ Equation 12-29, Highway Safety Manual Urban-Suburban Equations. 
Table 14. Crash Modification Factor $\left(C M F_{1 p}\right)$ for the Presence of Bus Stops near the Intersection

\begin{tabular}{|c|c|}
\hline $\begin{array}{c}\text { Number of Bus Stops within } 1,000 \mathrm{ft} \text { of the } \\
\text { Intersection }\end{array}$ & $\boldsymbol{C M F}_{\mathbf{1} \boldsymbol{p}}$ \\
\hline 0 & 1.00 \\
\hline 1 or 2 & 2.78 \\
\hline 3 or more & 4.15 \\
\hline
\end{tabular}

Table 15. Crash Modification Factor $\left(C M F_{2 p}\right)$ for the Presence of Schools near the Intersection

\begin{tabular}{|c|c|}
\hline $\begin{array}{c}\text { Number of Schools within } 1,000 \mathrm{ft} \text { of the } \\
\text { Intersection }\end{array}$ & $\boldsymbol{C M} \boldsymbol{F}_{\mathbf{2 p}}$ \\
\hline No school present & 1.00 \\
\hline School present & 1.35 \\
\hline
\end{tabular}

Table 16. Crash Modification Factor $\left(C M F_{3 p}\right)$ for the Number of Alcohol Sales Establishments near the Intersection

\begin{tabular}{|c|c|}
\hline $\begin{array}{c}\text { Number of Alcohol Sales Establishments } \\
\text { within } 1,000 \mathrm{ft} \text { of the Intersection }\end{array}$ & $\boldsymbol{C M F}_{\mathbf{3} \boldsymbol{p}}$ \\
\hline 0 & 1.00 \\
\hline $1-8$ & 1.12 \\
\hline 9 or more & 1.56 \\
\hline
\end{tabular}

The third element of the predictive model is the Local Calibration Factor. Because the HSM SPFs were developed using data from a subset of states, difference in crash data quality, roadway inventory, traffic counts, traffic reporting thresholds, and weather conditions may affect the prediction of the number and severity of crashes among states. For the predictive method to provide reliable results for each jurisdiction that uses them, several agencies have developed calibration factors. Figure 7 shows the Oregon DOT's local calibration factors. 


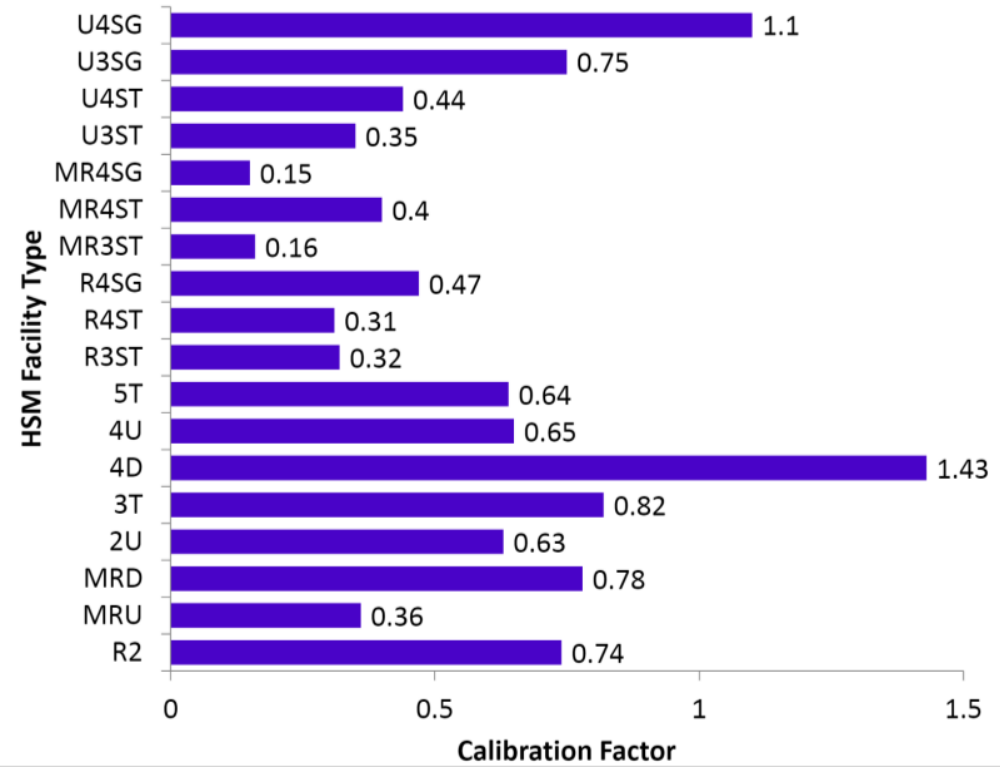

Figure 7. Local Calibration Factors developed for Oregon by ODOT for HSM Predictive Models

Once the appropriate predicted average crash frequency is calculated, the Empirical Bayes Method (EB method) can be used to calculate the expected average crash frequency for past and future periods at the site. This adjustment is only applied when observed crash data for a minimum of 2 years are available for the specific site. The EB method can reduce the effect of the regression-to-the-mean, which recognizes the fact that crashes are random events and over time an intersection with given characteristics will achieve the same amount of crashes on average. The EB method can be described as follows:

1. Combines actual site crash history with predicted average crash frequency.

2. Weights the two values based on the strength of the model (SPF), where the measure of the model's strength is referred to as the overdispersion parameter $(\mathrm{k})$.

Where:

$$
N_{\text {expected }}=w * N_{\text {predicted }}+(1.00-w) * N_{\text {observed }}
$$

$$
w=\frac{1}{\left[1+k *\left(\sum N_{\text {predicted }}\right)\right]}
$$

And:

$\mathrm{k}=$ overdispersion parameter

$\Sigma N_{\text {predicted }}=$ predictive model estimate for all study years

As the result of ODOT SPR 684, an intuitive spreadsheet can be used to calculate the predicted number of crashes per year at a given intersection.

The analysis section of this report will describe in further detail how the predicted number of crashes per year at each intersection were combined with observed crash frequency within the 
last five years of available crash data to generate the expected average crash frequencies, in addition to the calculation of risk estimations using exposure from pedestrian and vehicle counts.

\subsection{Field Measured Risk}

To calculate risk values according to observed historical crash and count data, vehicle and pedestrian AADT values and crash data will be combined using the following fundamental risk equation:

$$
\text { risk }=\frac{\text { crashes }}{\text { exposure }}
$$

In the development of the recently adopted Tillamook Transportation System Plan (TSP), twohour weekday PM peak hour (4-6pm) intersection counts were collected at the identified study intersections. ${ }^{12}$ Counts were then factored to average daily numbers following methodology developed by the National Bicycle and Pedestrian Documentation Project. ${ }^{13}$ The pedestrian average daily numbers were then multiplied by vehicle AADT $^{14}$ to estimate exposure at each intersection with the following equation:

$$
\text { Pedestrian Volume } * \text { Motor Vehicle Volume }=\text { Pedestrian Exposure }
$$

Documentation of pedestrian count factoring can be found in the Background section of this report.

\footnotetext{
${ }^{12}$ Counts collected on August 29, 2017 from 2-6pm.

${ }^{13}$ Count Adjustment Factors, National Bicycle and Pedestrian Documentation Project, March 2009.

${ }^{14}$ Major roadway AADT obtained from the ODOT TransGIS Database, Minor Roadway AADT calculated from intersection turning movement counts collected for the Tillamook TSP on August 29, 2017.
} 


\subsection{ANALYSIS}

The following section provides a table for each risk estimation method that describes the risk at each study intersection.

\subsection{ODOT SPR 779}

Risk values were determined for each study intersection according to the risk factors identified by ODOT SPR 779. Table 17 shows the resulting risk scores.

Table 17. ODOT SPR 779 Risk Scores

\begin{tabular}{|c|c|c|c|c|c|c|c|}
\hline Intersection & $\begin{array}{l}\text { Total Pop. Density } \\
\text { in Census Block }\end{array}$ & $\begin{array}{c}\text { Transit } \\
\text { Routes } \\
\text { through } \\
\text { Int. }\end{array}$ & $\begin{array}{l}\text { Major } \\
\text { AADT }\end{array}$ & $\begin{array}{l}\text { Presence of } \\
\text { Median on } \\
\text { Major } \\
\text { Road }\end{array}$ & $\begin{array}{c}\text { Minor } \\
\text { Road, } \\
\text { Presence of } \\
\text { RT lanes }\end{array}$ & $\begin{array}{c}\text { Major } \\
\text { Road, } \\
\text { Presence of } \\
\text { RT lanes }\end{array}$ & $\begin{array}{c}\text { Total } \\
\text { Risk } \\
\text { Score }\end{array}$ \\
\hline $\begin{array}{c}\text { 3rd Street / US } \\
101 \mathrm{SB}\end{array}$ & $>7000$ & $>2$ & $\begin{array}{l}5000- \\
10000\end{array}$ & $\begin{array}{c}\text { No } \\
\text { Presence }\end{array}$ & $\begin{array}{c}\text { No } \\
\text { Presence }\end{array}$ & $\begin{array}{c}\text { No } \\
\text { Presence }\end{array}$ & 62 \\
\hline $\begin{array}{l}\text { 3rd Street / US } \\
101 \text { NB }\end{array}$ & $>7000$ & $>3$ & $\begin{array}{c}5000- \\
10000\end{array}$ & $\begin{array}{c}\text { No } \\
\text { Presence }\end{array}$ & $\begin{array}{c}\text { No } \\
\text { Presence }\end{array}$ & $\begin{array}{c}\text { No } \\
\text { Presence }\end{array}$ & 79 \\
\hline $\begin{array}{c}\text { 4th Street / US } \\
101 \mathrm{SB}\end{array}$ & $5000-7000$ & 2 & $\begin{array}{l}5000- \\
10000\end{array}$ & $\begin{array}{c}\text { No } \\
\text { Presence }\end{array}$ & $\begin{array}{c}\text { No } \\
\text { Presence }\end{array}$ & $\begin{array}{c}\text { No } \\
\text { Presence }\end{array}$ & 54 \\
\hline $\begin{array}{c}\text { 4th Street / US } \\
101 \text { NB }\end{array}$ & $1000-3000$ & 3 & $\begin{array}{l}5000- \\
10000\end{array}$ & $\begin{array}{c}\text { No } \\
\text { Presence }\end{array}$ & $\begin{array}{c}\text { No } \\
\text { Presence }\end{array}$ & $\begin{array}{c}\text { No } \\
\text { Presence }\end{array}$ & 50 \\
\hline $\begin{array}{c}\text { 11th Street / US } \\
101 \mathrm{SB}\end{array}$ & $>7000$ & 2 & $\begin{array}{l}5000- \\
10000\end{array}$ & $\begin{array}{c}\text { No } \\
\text { Presence }\end{array}$ & $\begin{array}{c}\text { No } \\
\text { Presence }\end{array}$ & $\begin{array}{c}\text { No } \\
\text { Presence }\end{array}$ & 62 \\
\hline $\begin{array}{c}\text { 11th Street / US } \\
101 \text { NB }\end{array}$ & $>7000$ & 2 & $\begin{array}{l}5000- \\
10000\end{array}$ & $\begin{array}{c}\text { No } \\
\text { Presence }\end{array}$ & $\begin{array}{c}\text { No } \\
\text { Presence }\end{array}$ & $\begin{array}{c}\text { No } \\
\text { Presence }\end{array}$ & 62 \\
\hline
\end{tabular}

The intersection of $3^{\text {rd }}$ Street / US 101 NB was identified as the most risky intersection with the ODOT SPR 779 risk estimation method. As shown in the table above, it is the only intersection with more than three transit lines through the intersection and a higher ADT category.

\subsection{FHWA SCRAM}

Following the 8-step method provided in FHWA's Scalable Risk Assessment Guide, risk values were determined for each of the study intersections as "star" ratings. A higher star rating indicates a riskier intersection which should be prioritized for pedestrian safety improvements. Table 18 shows the star ratings for each intersection. 
Table 18. SCRAM Risk Scores

\begin{tabular}{|c|c|c|c|c|c|c|}
\hline Intersection & $\begin{array}{c}\text { Minor } \\
\text { Approach } \\
\text { FC }\end{array}$ & $\begin{array}{c}\text { Traffic } \\
\text { Control }\end{array}$ & $\begin{array}{c}\text { Proximity } \\
\text { of Transit } \\
\text { Stop }\end{array}$ & Volume & Exposure & $\begin{array}{c}\text { Total } \\
\text { Stars }\end{array}$ \\
\hline 3rd Street / US 101 SB & $*$ & $*$ & & $*$ & $* * *$ \\
\hline 3rd Street / US 101 NB & $*$ & $*$ & $*$ & $* *$ \\
\hline 4th Street / US 101 SB & & $*$ & $*$ & $*$ & $* * *$ \\
\hline 4th Street / US 101 NB & & $*$ & $*$ & $*$ & $* * *$ \\
\hline 11th Street / US 101 SB & & & $*$ & $*$ & $* *$ \\
\hline 11th Street / US 101 NB & & & $*$ & & $*$ & $* *$ \\
\hline
\end{tabular}

Five of the six study intersections received the same risk score using the SCRAM method, though notably the risk attributes that received stars for each intersection varied. There were similarities between intersections on the same minor roadway in terms of the factors that met a risky threshold.

\section{3 iRAP}

Risk values were determined for each study intersection according to the risk factors identified in the iRAP Methodology section of this report. Table 19 shows the resulting risk scores.

Table 19. iRAP Risk Scores

\begin{tabular}{|c|c|c|c|c|c|c|c|}
\hline \multirow[t]{2}{*}{ Intersection } & \multicolumn{6}{|c|}{ Likelihood Factors } & \multirow{2}{*}{$\begin{array}{l}\text { Risk } \\
\text { Score }\end{array}$} \\
\hline & Speed & $\begin{array}{c}\text { Number of } \\
\text { Lanes }\end{array}$ & $\begin{array}{c}\text { Intersection } \\
\text { Type }\end{array}$ & $\begin{array}{c}\text { Pedestrian } \\
\text { Crossing } \\
\text { Facilities }\end{array}$ & $\begin{array}{l}\text { Quality of } \\
\text { Crossing }\end{array}$ & $\begin{array}{l}\text { Vehicle } \\
\text { Parking }\end{array}$ & \\
\hline $\begin{array}{l}\text { 3rd Street / } \\
\text { US 101 SB }\end{array}$ & 0.01 & 0.02 & 45 & 1.25 & 1 & 1.2 & 0.014 \\
\hline $\begin{array}{l}\text { 3rd Street / } \\
\text { US } 101 \text { NB }\end{array}$ & 0.01 & 0.02 & 45 & 1.25 & 1 & 1.2 & 0.014 \\
\hline $\begin{array}{l}\text { 4th Street / } \\
\text { US } 101 \text { SB }\end{array}$ & 0.01 & 0.02 & 35 & 1.25 & 1 & 1.33 & 0.012 \\
\hline $\begin{array}{l}\text { 4th Street / } \\
\text { US } 101 \text { NB }\end{array}$ & 0.01 & 0.02 & 45 & 1.25 & 1 & 1.33 & 0.015 \\
\hline $\begin{array}{c}\text { 11th Street / } \\
\text { US } 101 \mathrm{SB}\end{array}$ & 0.019 & 0.02 & 70 & 4.8 & 1 & 1.33 & 0.170 \\
\hline $\begin{array}{l}\text { 11th Street / } \\
\text { US } 101 \text { NB }\end{array}$ & 0.019 & 0.02 & 70 & 4.8 & 1 & 1.33 & 0.170 \\
\hline
\end{tabular}

As the only method that did not use exposure data in the risk estimation process, both intersections on $11^{\text {th }}$ Street were identified as the most risky according to the iRAP methodology. These intersections have less protection from vehicles for pedestrians in terms of actual pedestrian infrastructure, though pedestrian counts were so much lower at this intersection that other methods inclusion of exposure minimized the risk calculations on $11^{\text {th }}$ Street. The results of the iRAP method could suggest that though there are fewer pedestrians on $11^{\text {th }}$ Street, they are experiencing higher levels of risk and potential for crashes with motor-vehicles. 


\subsection{HSM Predictive Models and Field Measured Exposure}

Risk values were determined for each study intersection according to the predictive method described in the HSM in conjunction with field measured exposure via vehicle and pedestrian AADT values. ${ }^{15}$ Table 20 shows the resulting risk scores and ranking of intersections. An additional column for ranking is provided for clearer determination of which intersections have higher pedestrian risk.

Table 20. HSM Predictive Model and Field Measured Exposure Risk Scores

\begin{tabular}{|c|c|c|c|c|c|c|}
\hline Intersection & $\begin{array}{c}\text { Predicted } \\
\text { Average } \\
\text { Crash } \\
\text { Frequency }\end{array}$ & $\begin{array}{c}\text { Observed } \\
\text { Crash } \\
\text { Frequency }\end{array}$ & $\begin{array}{c}\text { Expected } \\
\text { Average } \\
\text { Crash } \\
\text { Frequency }\end{array}$ & Exposure & $\begin{array}{c}\text { Risk } \\
\text { (crashes / } \\
\text { exposure) }\end{array}$ & Ranking \\
\hline 3rd Street / US 101 SB & 0.324 & 1 & 0.51 & 5475023 & $9.37 \mathrm{E}-08$ & 2 \\
\hline 3rd Street / US 101 NB & 0.35 & 1 & 0.54 & 4760890 & $1.14 \mathrm{E}-07$ & 1 \\
\hline 4th Street / US 101 SB & 0.275 & 1 & 0.46 & 6611349 & $6.88 \mathrm{E}-08$ & 3 \\
\hline 4th Street / US 101 NB & 0.242 & 0 & 0.19 & 4958512 & $3.78 \mathrm{E}-08$ & 4 \\
\hline 11th Street / US 101 SB & 0.007 & 1 & 0.02 & 619814 & $2.46 \mathrm{E}-08$ & 5 \\
\hline 11th Street / US 101 NB & 0.007 & 1 & 0.02 & 898281 & $1.70 \mathrm{E}-08$ & 6 \\
\hline
\end{tabular}

Similar to the ODOT SPR 779 risk estimation method, $3^{\text {rd }}$ Street / US 101 NB was identified as the most risky study intersection. The HSM Predictive Method uses CMFs that account for pedestrian generators such as transit stops and convenience stores that sell alcohol therefore placing additional weight on exposure rates at each intersection, which likely explains the similar result to the ODOT method.

\subsection{Field Measured Risk}

Risk values were determined for each study intersection according to the risk equation described previously in the Methodology section. Table 21 shows the resulting risk scores and ranking of intersections. An additional column for ranking is provided for clearer determination of which intersections have higher pedestrian risk.

Table 21. Field Measured Risk Scores

\begin{tabular}{|c|c|c|c|c|}
\hline Intersection & Exposure & Crashes & Risk (crashes / exposure) & ranking \\
\hline 3rd Street / US 101 SB & 5475023 & 1 & $1.83 \mathrm{E}-07$ & 2 \\
\hline 3rd Street / US 101 NB & 4760890 & 1 & $2.10 \mathrm{E}-07$ & 1 \\
\hline 4th Street / US 101 SB & 6611349 & 1 & $1.51 \mathrm{E}-07$ & 3 \\
\hline 4th Street / US 101 NB & 4958512 & 0 & $0.00 \mathrm{E}+00$ & 6 \\
\hline 11th Street / US 101 SB & 619814 & 1 & $1.61 \mathrm{E}-06$ & 5 \\
\hline 11th Street / US 101 NB & 898281 & 1 & $1.11 \mathrm{E}-06$ & 4 \\
\hline
\end{tabular}

${ }^{15}$ Vehicle AADT on major roadways estimated using the ODOT TransGIS database. Vehicle AADT on minor roadways and Pedestrian AADT estimated using traffic counts taken for the adopted Tillamook TSP on August 29, 2017. 
Due to the low number of crashes at the study intersections during the analysis period, the simplified field measured risk is also placing higher weight on exposure values, resulting in similar risk estimations to the HSM Predictive Method and the ODOT SPR 779 report. 


\subsection{RESULTS AND DISCUSSION}

Table 22 provides a summary of the comprehensive risk values for all six study intersections' according to the five risk estimation methods analyzed. Lower rankings indicate intersections that should be prioritized for pedestrian safety improvements, where a ranking of 1 indicates the highest amount of risk.

Table 22. Comparison of Risk Estimation Models at each Study Intersection

\begin{tabular}{|c|c|c|c|c|c|c|}
\hline Intersection & $\begin{array}{c}\text { ODOT } \\
\text { SPR 779 }\end{array}$ & $\begin{array}{c}\text { FHWA } \\
\text { SCRAM }\end{array}$ & iRAP & $\begin{array}{c}\text { HSM } \\
\text { Predictive }\end{array}$ & $\begin{array}{c}\text { Field } \\
\text { Measured }\end{array}$ & $\begin{array}{c}\text { Final } \\
\text { Ranking }\end{array}$ \\
\hline 3rd Street / US 101 SB & 2 & 1 & 4 & 2 & 2 & 11 \\
\hline 3rd Street / US 101 NB & 1 & 1 & 4 & 1 & 1 & 8 \\
\hline 4th Street / US 101 SB & 5 & 1 & 6 & 3 & 3 & 18 \\
\hline 4th Street / US 101 NB & 6 & 1 & 3 & 4 & 6 & 20 \\
\hline 11th Street / US 101 SB & 2 & 1 & 1 & 5 & 5 & 15 \\
\hline 11th Street / US 101 NB & 2 & 2 & 1 & 6 & 4 & 15 \\
\hline
\end{tabular}

With the lowest final ranking of 8 points, $3^{\text {rd }}$ Street and US 101 NB was identified as the mostrisky study intersection. As one of the intersections with the highest vehicle and pedestrian AADT values, this ranking seems to be logical in terms of exposure alone. Its proximity to transit lines and transit stops also likely contribute to pedestrian volumes and increases exposurerelated risk factors included in many of the estimation methods.

The intersection of $4^{\text {th }}$ Street and US 101 NB received the highest final ranking of 20 points, indicating that it should have the lowest priority for pedestrian safety improvement projects. This intersection was the only intersection that did not have a crash in the last five years of available crash data.

Potentially as a result of risk factor inputs, intersections located on the same minor roadways were grouped together in the final ranking. Table 23 describes this observation. This trend may also be attributed to the short block distance between the northbound and southbound legs of the couplet, resulting in fewer differences between intersections on either direction of US 101.

Table 23. Minor Roadway Trend among Study Intersection Rik Ranks

\begin{tabular}{|c|c|}
\hline Minor Roadway & Intersection (Rankings) \\
\hline $3^{\text {rd }}$ Street & US 101 SB (8), US 101 NB (11) \\
\hline $\mathbf{1 1}^{\text {th }}$ Street & US 101 SB (15), US 101 NB (15) \\
\hline $\mathbf{4}^{\text {th }}$ Street & US 101 SB (18), US 101 NB (20) \\
\hline
\end{tabular}




\subsection{Frequently used Inputs/Data Requirements}

Though each pedestrian risk estimation model had its own risk factors, common inputs and data requirements emerged after completing analyses for all methods. The following list of risk factors occurred in more than one risk estimation method:

- Presence/Proximity of Transit Lines or Stops

- Motor Vehicle Volume

- Pedestrian Volume

- Presence of Vehicle Turn Lanes

- Number of Vehicle Lanes

Following the definition of risk for pedestrians that exposure and infrastructure quality (probability) are related to the consequence, the mixture of exposure variables and infrastructure quality variables that were common among the methods analyzed in this report is logical. In addition, risk factors for the ODOT SPR 779 report and the FHWA SCRAM analysis were developed by looking at other risk estimation methods and what may contribute most to a lack of pedestrian safety. The following subsection will discuss an overall review of the risk estimation methods used in this report.

\subsection{The Gouda, the Bad, and the Ugly}

\section{The Gouda}

The risk estimation model developed by ODOT SPR 779 seemed to have the most risk factors in common with other estimation models and would be recommended for use in future project prioritization analyses. The methodology behind the ODOT SPR 779 model was developed through a comprehensive literature review of multiple methods, including the iRAP and HSM Predictive methodologies. In addition, it's risk estimation was most similar to the cumulative risk estimations for all of the methodologies.

\section{$\underline{\text { The Bad }}$}

As mentioned previously in this report, using a simplified definition of risk that only includes exposure and crashes is an incomplete way to prioritize intersections for pedestrian safety. As identified by using a combination of risk estimation methods, pedestrian volumes were not as high at the study intersections on $11^{\text {th }}$ Street but including infrastructure elements in risk scoring allows the analysis to quantify poor quality that is experienced in the field. Without quantification of infrastructure conditions, unsafe intersections could go overlooked if pedestrians are not crossing there.

\section{$\underline{\text { The Ugly }}$}

Arguably, any pedestrian on the roadway should be protected whether they are a part of a larger group of pedestrians or not. Pedestrian risk estimation methods that place a heavy weight on exposure values may be oversimplifying the nature of pedestrian traffic and how the attractiveness and safety of a crossing may impact how many pedestrians cross there. The 
ultimate goal of identifying pedestrian projects within a TSP process is to make the overall pedestrian system better throughout a city or region, therefore building out a safe network can promote pedestrian activity at intersections that currently experience lower crossing volumes. It is the job of transportation engineers and planners to analyze a network holistically, which a number of the risk estimation methods analyzed in this report do. "The Ugly" can only happen when pedestrians are overlooked. 


\subsection{REFERENCES}

Berdica, K. "An Introduction to Road Vulnerability: What Has Been Done, Is Done and Should be Done. Transport Policy, Vol. 9 No. 2, 2002.

City of Tillamook, Transportation System Plan Update, 2018.

Count Adjustment Factors, National Bicycle \& Pedestrian Documentation Project, March 2009.

International Roadway Assessment Programme, iRAP Model Fact Sheets:

- Full Reference List

- Operating Speed

- Pedestrian Crossing Facilities

- Vehicle Parking

- External Flow

- Star Rating Score Worked Example

- Coding Manual

Updated 2013.

Kolody, K., Perez-Bravo, D., Zhao, J., Neuman, T.R. "Highway Safety Manual User Guide,” FHWA/AASHTO, NCHRP 17-50, 2014.

Lynam, D. "Development of Risk Models for the Road Assessment Programme," EuroRAP, 2012.

Monsere, Chris, H. Wang, Y. Wang, and C. Chen. "Risk Factors for Pedestrian and Bicycle Crashes," ODOT Research Section, May 2017.

Turner, Shawn, et. Al. "Guide for Scalable Risk Assessment Methods for Pedestrians and Bicyclists," United States Department of Transportation, Federal Highway Administration. 2018.

United States Department of Transportation, Federal Highway Administration. Highway Safety Manual, 2010. 